\title{
Fungal Enzymes and Yeasts for Conversion of Plant Biomass to Bioenergy and High- Value Products
}

\author{
Lange, Lene
}

Published in:

Microbiology Spectrum

Link to article, DOI:

10.1128/microbiolspec.FUNK-0007-2016

Publication date:

2017

Document Version

Publisher's PDF, also known as Version of record

Link back to DTU Orbit

Citation (APA):

Lange, L. (2017). Fungal Enzymes and Yeasts for Conversion of Plant Biomass to Bioenergy and High-Value Products. Microbiology Spectrum, 5(1). https://doi.org/10.1128/microbiolspec.FUNK-0007-2016

\section{General rights}

Copyright and moral rights for the publications made accessible in the public portal are retained by the authors and/or other copyright owners and it is a condition of accessing publications that users recognise and abide by the legal requirements associated with these rights.

- Users may download and print one copy of any publication from the public portal for the purpose of private study or research.

- You may not further distribute the material or use it for any profit-making activity or commercial gain

- You may freely distribute the URL identifying the publication in the public portal

If you believe that this document breaches copyright please contact us providing details, and we will remove access to the work immediately and investigate your claim. 


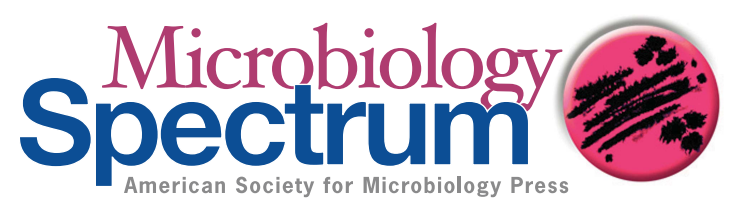

\section{Fungal Enzymes and Yeasts for Conversion of Plant Biomass to Bioenergy and High-Value Products}

LENE LANGE

Technical University of Denmark, Department of Chemical and Biochemical Engineering, Center for Bioprocess Engineering, 2800 Kgs. Lyngby, Denmark

\begin{abstract}
Fungi and fungal enzymes play important roles in the new bioeconomy. Enzymes from filamentous fungi can unlock the potential of recalcitrant lignocellulose structures of plant cell walls as a new resource, and fungi such as yeast can produce bioethanol from the sugars released after enzyme treatment. Such processes reflect inherent characteristics of the fungal way of life, namely, that fungi as heterotrophic organisms must break down complex carbon structures of organic materials to satisfy their need for carbon and nitrogen for growth and reproduction. This chapter describes major steps in the conversion of plant biomass to value-added products. These products provide a basis for substituting fossil-derived fuels, chemicals, and materials, as well as unlocking the biomass potential of the agricultural harvest to yield more food and feed. This article focuses on the mycological basis for the fungal contribution to biorefinery processes, which are instrumental for improved resource efficiency and central to the new bioeconomy. Which types of processes, inherent to fungal physiology and activities in nature, are exploited in the new industrial processes? Which families of the fungal kingdom and which types of fungal habitats and ecological specializations are hot spots for fungal biomass conversion? How can the best fungal enzymes be found and optimized for industrial use? How can they be produced most efficiently-in fungal expression hosts? How have industrial biotechnology and biomass conversion research contributed to mycology and environmental research? Future perspectives and approaches are listed, highlighting the importance of fungi in development of the bioeconomy.
\end{abstract}

\section{THE ROLE OF FUNGI IN CONVERSION OF PLANT BIOMASS \\ The Increasing Importance of Fungi in Biotechnology}

Fungi are now widely used in industrial biotechnology, for example, as production hosts for technical and food and feed processing enzymes, as gene donors for such enzymes, as production hosts for organic acids and cholesterol-lowering drugs (the statins), and as starter cultures and probiotics (1). Around half of the industrial enzymes used globally are of fungal origin; the other half are of bacterial origin. However, this balance is now moving toward the use of more enzymes from a wider spectrum of families of the fungal kingdom. There are several reasons for this. Fungal enzymes are efficient,

\footnotetext{
Received: 1 March 2016, Accepted: 20 April 2016,

Published: 3 February 2017.

Editors: Joseph Heitman, Department of Molecular Genetics and Microbiology, Duke University Medical Center, Durham, NC 27710;

Eva Holtgrewe Stukenbrock, Environmental Genomics,

Christian-Albrechts University of Kiel, Kiel, Germany, and Max

Planck Institute for Evolutionary Biology, Plön, Germany

Citation: Lange L. 2017. Fungal enzymes and yeasts for conversion of plant biomass to bioenergy and high-value products. Microbiol Spectrum 5(1):FUNK-0007-2016. doi:10.1128/microbiolspec.FUNK0007-2016.

Correspondence: Lene Lange, lenlakt.dtu.dk

(c) 2017 American Society for Microbiology. All rights reserved.
} 
compatible, and suitable for industrial processing: they have sufficient protein stability to give the enzyme products an acceptable shelf life; they provide customer solutions, meet regulatory approval demands, and fulfill end user needs.

The driver for this increased importance of fungi and fungal enzymes is the development of the new bioeconomy, where crop residues, industrial by-products, and organic waste streams are used as a basis for producing more bio-based products, obtaining more from biological resources, and wasting less (see Fig. 1). The potential is huge. Currently, there is a global loss of 30 to $50 \%(2)$ of all agricultural production, when summing up losses through the value chain from field to end user. Because of this, it is predicted that fungal enzymes will be vital for moving from a fossil-based to a renewablesbased world economy, where upgrade of lignocellulosic biomass leads to production of not only biofuels, but also bio-based materials and bio-based chemicals, as well as new and healthier feed and food ingredients $(\underline{3}, \underline{4})$.

Development toward a bioeconomy places fungi and mycology in a central position in relation to mitigating climate change; improving resource efficiency; replacing fuels, chemicals, and materials based on fossil resources; and contributing to feeding a growing global population. The next generation of products from biomass will utilize the intact structural complexity of the fresh biomass for health-promoting food and feed ingredients.

\section{Fungal Enzymes, the Choice for Biomass Conversion: For Bioenergy and Beyond}

Fungi have three roles in making value from plant biomass:

- As gene donors for large-scale production of enzymes

- As industrial production hosts for biomass-degrading enzymes and metabolites

- As producers of biorefinery end products (e.g., bioethanol, organic acids, biochemicals, or singlecell proteins) resulting from their growth on sugars from the enzymatic conversion of plant biomass

One of the most significant lifestyle characteristics of filamentous fungi is that they secrete enzymes. Secretion

FIGURE 1 A schematic overview of a biorefinery. The product portfolio from biorefineries is not only fuels and chemicals but also includes higher-value products such as food and feed ingredients, cosmetics, skin care, and new functional biomaterials; it is also expected that many types of biorefineries will be developed for improved resource efficiency: the yellow (straw, stover, and wood chips), the green (fresh grass, clover, leaves), the blue (seaweed and fish bycatch and waste), the gray (agroindustrial side streams), and a biorefinery for upgrade of household waste and sludge (the brown biorefinery). Adapted from reference 16 with permission.
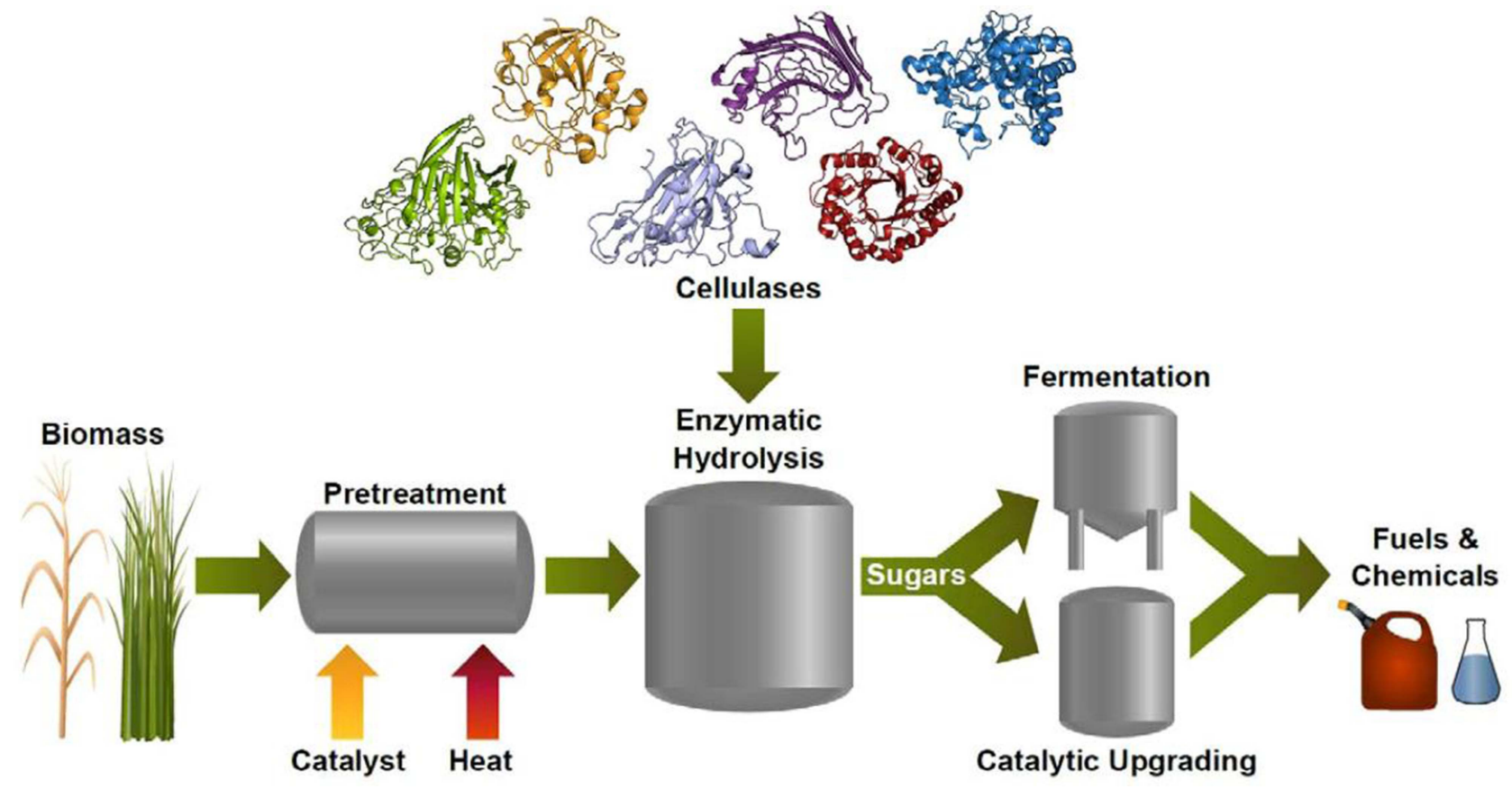
occurs primarily from the tip cells of the growing hyphae $(\underline{5}, \underline{6})$. In nature, a large proportion of the secreted enzymes break down the substrate (e.g., plant tissue) that the fungus invades. In natural habitats, such enzymatic biocatalysis of the substrate results in a conversion of the plant biomass into smaller building blocks suitable for hyphae to absorb for further growth of the fungus.

Through evolution, the growth of filamentous fungi has been adapted for efficiency in substrate utilization. The main adaptive traits are that (i) secreted fungal enzymes have a complement of activities for breaking down the substrate polymers, (ii) the enzymes are also stable outside the fungal cell, and (iii) the enzymes are available and are actively degrading the substrate at the time when the fungal hyphae have reached the area into which the enzymes have diffused. This allows the fungus to take up nutrients quickly after the degradation products have become available. Enzymatic breakdown thus primarily benefits the growth of the fungus itself rather than merely making substrate available for competitors such as bacteria or other fungi.

Almost all commercialized enzymes for industrial purposes (for example, in the detergent, textile, juice, paper, or baking industries) are enzymes (with a signal peptide for secretion) that in nature are secreted from the fungal cell which produces them. The reason for this is that secreted enzymes in general are more stable and significantly cheaper to produce because they can be recovered directly from large-scale fermentation broth without the necessity of opening the fungal cells.

Secreted, stable proteins suitable for large-scale, costefficient production can match the cost structure and price window of the industrial processes in question. Such proteins fulfill the primary industrial requirements, namely, high enzyme yields, easy recovery from fermentation broth, and good protein stability-all in all, giving lasting performance and end user benefits.

\section{Overview of Secreted Enzymes from Filamentous Fungi}

In the fungal kingdom a large spectrum of secreted enzymes has evolved to predigest organic structures into smaller molecules suitable for uptake by the fungal cell. Through evolution, fungal enzymes have been developed to break down almost all organic substrates available on earth (see the CAZy database []]). The greatest diversity of enzyme activities described is related to the breakdown of plant cell wall structures. The CAZy database is described on its homepage as "a specialist database, dedicated to the display and analysis of genomic, structural and biochemical information on Carbohydrate-Active Enzymes (CAZymes)." The CAZy database includes well-curated information about the following types of enzymes derived from all parts of the biological kingdoms: glycoside hydrolases (GHs) (hydrolysis and/or rearrangement of glycoside bonds), glycosyl transferases (formation of glycosidic bonds), polysaccharide lyases (nonhydrolytic cleavage of glycosidic bonds), carbohydrate esterases (hydrolysis of carbohydrate esters), and auxiliary activities (AAs) (redox enzymes that act in conjunction with CAZymes) (www .CAZy.org). In nature, fungal enzymes have been described that belong to all of these five groupings (GHs, glycosyl transferases, carbohydrate esterases, and AAs). Efficient conversion of biomass involves enzymes of all these major groups of carbohydrate active enzymes; $\mathrm{GH}$ cellulases and hemicellulases play the biggest role.

\section{Biomass Conversion Enzymes Found Throughout the Fungal Kingdom and in Many Habitats}

Genes encoding secreted enzymes are found in all divisions of the fungal kingdom. Based on the fungal enzymes included in the CAZy database, the richest portfolio of enzymes are in the Ascomycota, followed by the Basidiomycota, and lastly, the Zygomycota, whose members primarily produce enzymes suitable for releasing sugar molecules from already partially degraded products. Preliminary studies of the Chytridiomycota and Neocallimastigomycota document that at least selected species of these early-lineage fungi also have a wide portfolio of lignocellulosic polymer-degrading enzymes ( $\underline{8})$.

The most complex organic structures in plants and fungi are their cell walls. A huge number of different types of enzymes are needed for total breakdown of the plant cell walls of both monocots and dicots. Fungi specializing in degrading plant biomass in nature thus have a very broad portfolio of plant cell wall-degrading enzymes. Analysis and clustering of a broad spectrum of genome sequences of secretome enzymes from Ascomycetes, Basidiomycetes, and Zygomycetes gave a surprising result $(\underline{9}, \underline{10})$ : the clustering into being a good lignocellulose degrader or not was a more prominent trait than the fungal phyla to which the enzyme-producing fungi belonged. Thus, the phenotypic characteristic of the enzyme secretome portfolio overruled the taxonomic position.

Plant cell wall-degrading enzymes can be found in a vast spectrum of fungal habitats and life forms (Table 1 ). The most studied are white rot, brown rot, and soft rot fungi, as well as saprophytic fungi on dead herbaceous 
Q13 TABLE 1 A selection of well-studied lignocellulose degraders across the fungal kingdom

\begin{tabular}{|c|c|c|c|}
\hline Fungal phyla & Fungal species & Fungal order & Physiology and habitat \\
\hline Basidiomycota & $\begin{array}{l}\text { Phaenerochaete chrysosporium } \\
\text { Schizophyllum commune } \\
\text { Postia placenta } \\
\text { Gloeophyllum trabeum } \\
\text { Ganoderma applanatum } \\
\text { Termitomyces spp. } \\
\text { Leucoagaricus gongylophorus }\end{array}$ & $\begin{array}{l}\text { Polyporales } \\
\text { Agaricales } \\
\text { Polyporales } \\
\text { Gloeophylales } \\
\text { Polyporales } \\
\text { Agaricales } \\
\text { Agaricales }\end{array}$ & $\begin{array}{l}\text { White rot } \\
\text { Putative white rot } \\
\text { Brown rot } \\
\text { Brown rot } \\
\text { Heart rot } \\
\text { Termite symbiont } \\
\text { Leaf cutter ant symbiont }\end{array}$ \\
\hline
\end{tabular}

and wooden plant materials (11); interesting enzymes are also found from extremophiles (fungi growing in extreme environments) (12).

Plant cell wall-degrading enzymes are also produced by plant pathogenic fungi ( $\underline{5})$ and by ectomyccorhizal fungi (13). Another biomass conversion habitat is that of coprophilic fungi, which grow on animal dung. Very prolific cellulase producers include Podospora spp. (14, 15). Coprophilic cellulase producers also typically secrete a range of bioactive metabolites and are found to be a better source of antimicrobial metabolites than most other cellulose-producing fungi: for coprophiles, substrate becomes available all at once, and the limiting factor for gaining access to the substrate is to outcompete other microbes present in the dung materials. In contrast, competition for access to substrate is not the primary parameter for plant pathogens. The infection process is very complex and depends primarily on breaking host resistance barriers.

\section{PLANT CELL WALL-DEGRADING ENZYMES FROM FUNGI \\ The Recalcitrance of Lignocellulose and How To Overcome It}

Lignocellulose is a highly complex and varying polymeric structure. It is the basic structure and major component of plant cell walls and has been developed through evolution to resist both biotic and abiotic stress, such as microbial pathogens and damage from wind and weather (16). Lignocellulose is composed of four major components: cellulose ( 20 to $50 \%$ ), hemicellulose (15 to $35 \%$ ), lignin (10 to $30 \%$ ) (16), and pectin (often a rather low percentage). The lignocellulosic structure is highly recalcitrant to degradation, due to close packing of very complex, interlinked components. The branched hemicellulose coats the cellulose microfibers, the lignin encapsulates the polysaccharide components (cellulose, hemicellulose, and pectin) like a matrix around all polymeric structures, and the crystalline cellulose fibers themselves form a very recalcitrant structure, adding to inaccessibility and robustness. Due to this structural complexity and the interwoven, closely packed components, enzymes cannot readily access the plant cell wall components. Therefore, prior to industrial enzyme hydrolysis, a chemical/physical pretreatment is performed, which breaks down the lignocellulose structure sufficiently to allow enzymatic degradation.

Attempts have been made to develop more gentle pretreatment processes, for example, by using biocatalysis. The cellobiohydrolase enzyme family GH7 and laccases have been suggested for this purpose $(\underline{17}, \underline{18})$ along with the use of family GH45-like proteins named expansins $(\underline{19}, \underline{20})$, swollenins (21), and loosenins (16); lactic acid bacteria fermentation can also be used (16). Such gentler pretreatment could cut down energy costs and result in a hydrolyzed biomass that is more suitable as a base for upgrading, and it would not have the negative consequences of harsh pretreatments (e.g., artifacts, relocated lignin, and antinutritional factors). 
Nature's biomass conversion processes have inspired research into the development of gentler pretreatment procedures. For instance, several Ascomycetes and $B a-$ sidiomycetes can grow directly on and in a beech tree trunk; Hypoxylon fragiforme and Schizophyllum commune attack freshly fallen branches and trunks of deciduous trees, and Fomes fomentarius and Ganoderma applanatum cause heart rot on deciduous trees such as beech (22). Apparently, no pretreatment (physical or chemical) takes place. The fungi establish and grow, breaking down lignocellulose to fulfill their requirement for carbon. Time is obviously a factor, and changes over time in environmental conditions (humidity, temperature, light) play a role. However, molecules including the expansins, swollenins, and loosenins $(\underline{16}, \underline{19}-21)$ most likely also play a role. In addition, as yet undescribed synergies between chemical (reactive oxygen, photons, or metals) and biocatalytic reactions are probably involved. Interestingly, pretreatment is not required when aquatic biomass is used as biorefinery feedstock, because aquatic biomass has no or very little lignin in the cell walls.

\section{Enzymatic Decomposition of Lignocellulose Lignocellulose}

Collective action among several enzymes is required to break down the complicated lignocellulosic structure. The most important group of enzymes for these activities is glycohydrolases, GH enzymes which cleave glycoside linkages (ㄱ). Such linkages are dominant in both cellulose and hemicellulose. Furthermore, polysaccharide esterases (carbohydrate esterases in the CAZy database [7]) assist the hydrolysis of GH enzymes by removing the methyl, acetyl, and phenolic esters. Polysaccharide lyases may also play a role in depolymerization. Several types of fungi, from a broad variety of habitats and taxonomic groupings, have all the enzymes needed for complete breakdown of lignocellulosic plant cell wall structures (see Table 1, above, and Fig. 3 , below) (모 $\underline{16}, \underline{23}-\underline{29})$.

\section{Cellulose and cellulases}

Depolymerization of cellulose fibers requires the following enzymatic activities: an endoglucanase acting on cellulose (EC 3.2.1.4), two types of cellobiohydrolase (exoglucanases), one of which acts on the reducing end of the polymer (EC 3.2.1.177) and the other on the nonreducing end (EC 3.2.1.96), one $\beta$-glucosidase which cleaves the dimeric cellobiose to monomer C6 sugar/ glucose (EC 3.2.1.21 $\beta$-glucosidase), plus the action of the lytic polysaccharide monooxygenases (LPMOs) (see Fig. 2A).
The occurrence of several $\beta-1,4$ endoglucanase-active enzymes (EC 3.2.1.4, of GH5, GH9, GH45) in a fungus is interpreted as reflecting a robust degrader whose enzymes contribute to improved fitness. This is because as a result, the fungus has built-in flexibility and can produce the enzymes most suitable for several types of environmental conditions (humidity, temperature, $\mathrm{pH}$, etc.) (2).

Cellulases are divided into processive and nonprocessive; endoglucanases (EC 3.2.1.4) belong to the latter, and the cellobiohydrolases, GH6 and GH7, to the former. Furthermore, the hydrolytic activity can belong to the inverting (one-step) or the retaining (two-step) process (16). Among the active enzymes of the EC 3.2.1.4 class, GH45 is the only one of the inverting type.

Another prominent feature of cellulases in both nature and under industrial conditions relates to whether they are closely associated with the substrate, not just through interaction at the active site but also with a carbohydrate binding domain (CBM). The CBM can be located at either the $\mathrm{N}$ - or the C-terminal end (or in rare cases both) (30). CBMs can affect the efficacy and speed of enzyme activity; fungal CBMs primarily belong to the CBM1 family. Furthermore, whether the linker region that spans the catalytic domain and CBM is short or long also affects the behavior of the enzyme (27). CBM and linker modifications are such powerful tools for the design of enzymes and enzyme processes that they have been the basis of several patents and research and development $(\mathrm{R} \& \mathrm{D})$ business strategies.

\section{Hemicellulose and hemicellulases}

The depolymerization of heavily branched and substituted hemicellulose structures also requires an entire complement of enzymes. At least one kind of endoxylanase (e.g., GH10 or GH11) is needed $(\underline{7}, \underline{31})$ to break the xylan backbone. The endoxylanase activity (EC 3.2.1.8) is assisted by a range of other hemicellulases, usually by synergistic activity among the following types of enzymes: acetyl xylan esterase, arabinofuranosidase, and ferulic acid esterase (32-37) (Fig. 2B).

The reason why many of the hemicellulase enzymes have not been included in commercialized enzyme blends for lignocellulose decomposition is that many of the linkages cleaved by such enzymes are already broken during the pretreatment processing.

\section{Lignin}

Lignin is a very different type of polymeric substance compared to cellulose and hemicellulose, because it is a heterogeneous alkyl-aromatic polymer. Lignin degra- 


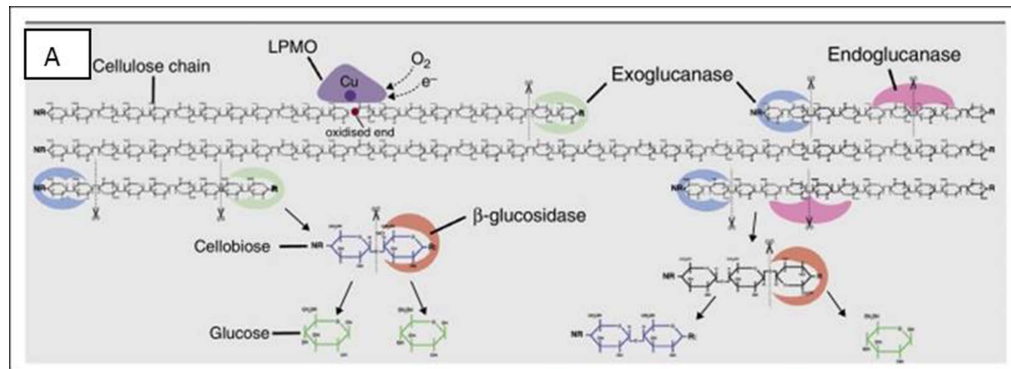

B Classic model OF ENZYMATIC Hemicellulose DEgRAdATION

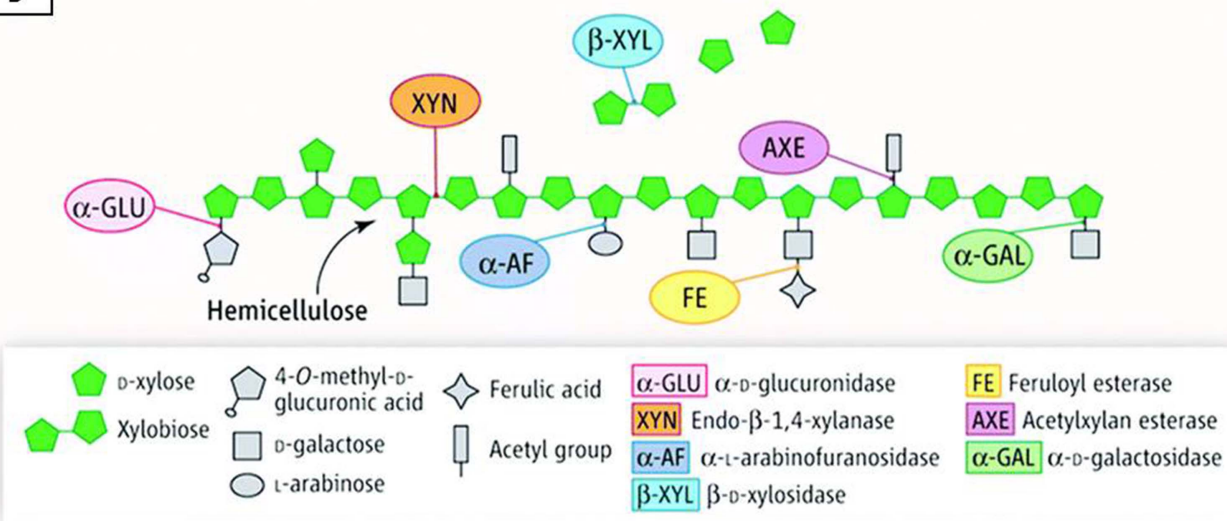

FIGURE 2 (A) Enzymatic breakdown of cellulose polymer includes several glycohydrolases (at least one endoglucanase, at least two cellobiohydrolases, reducing end and non-reducing-end active, and at least one $\beta$-glucosidase). Further, the activity of a lytic polysaccharide monooxygenase acts in synergy with the endoglucanase in breaking down the crystallinity of the cellulose polymer. Adapted from reference 24 with permission. (B) Hemicellulose is a very complex, highly branched and substituted polymer. The figure shows seven types of sugar components and lists the seven types of enzymes needed to break the linkages to such sugar moieties. However, enzyme hydrolysis of lignocellulose may not need the presence of all these seven hemicellulases because most of the standard pretreatment procedures will lead to the breakdown of several of the hemicellulose bonds. Adapted from reference $\underline{37}$ with permission.

dation by white rot basidiomycetous fungi has been more studied than any other type of fungi ( $\underline{38})$. The most prominent types of enzymes active in lignin degradation are laccases and peroxidases (both types are oxidative enzymes) (17, 39-41). However, such enzymes do not react independently, and mediators are needed. Brown rot fungi such as Coniophora puteana and Serpula lacrymans do not have prominent lignin-degrading enzymes, but such fungi do modify (through the action of specialized reactive metabolites) the lignin surface structure, thus freeing the cellulosic components from the lignin. The modified lignin structure remains for years in nature without much further degradation. Research on lignin degradation has led to many new efforts in studying not only the classical brown rot and white rot fungi, but also many other fungal species in many habitats. From such new studies it appears that throughout the range of lignin-degrading fungi, there exists a continuum of biomass degradation regimes, with varying degrees of similarity to white rot and brown rot fungi (38).

A recent development in understanding the fungal decomposition of lignocellulosic structures is the discovery of a new type of enzymatic activity, which has a function significantly different from all of the biomass conversion enzymes mentioned above. The new kind of enzyme activity was revealed by applying enzyme discovery approaches that are independent of sequence or function similarity to known enzymes. Two approaches were used: (i) use of culture broth fractionation followed by estimation of lignocellulose decomposition potential of the various fractions and (ii) use of transposonassisted signal trapping (TAST) screening, a technique discussed later in this article (42). Both techniques demonstrated that a significant and novel type of enzyme, hitherto not associated with cellulose breakdown, 

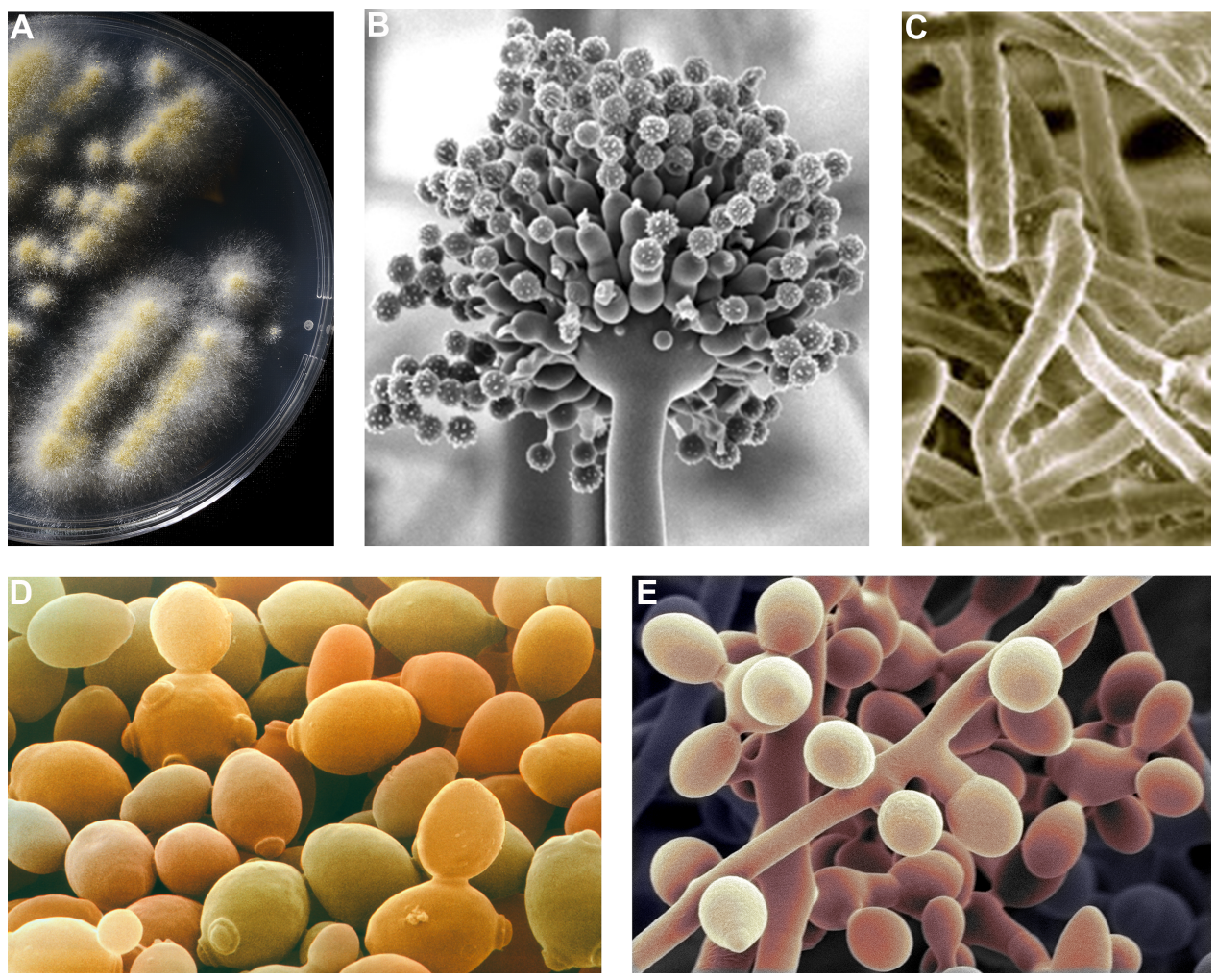

FIGURE 3 "Fungal Hall of Fame" illustrating the five most important players in industrial lignocellulose biorefinery processing and in research. (A) Aspergillus oryzae, along with (B) Aspergillus niger and Aspergillus nidulans, are the most widely used monocomponent enzyme production organisms. (C) Trichoderma reesei is included due to its exceptional secretion capacity; it is the preferred production host for enzyme blends specifically designed for efficient biomass conversion. (D) Saccharomyces cerevisiae is the organism of choice for production of ethanol from the biomass conversion-derived sugar platform. Pichia pastoris is the expression host most often used for producing laboratory-scale volumes of newly discovered enzymes to facilitate characterization and evaluation of the new enzymes for industrial potentials. (E) Myceliophthora thermophilae, along with another thermophilic fungus, Thermoascus aurantiacus, represents alternatives to production of enzymes by species of Aspergillus. Credits: (A) Courtesy of Reinhard Wilting, Novozymes A/S; (B) from Read ND, in Electron Microscopy of Plant Pathogens (Mendgen K, Lesemann D-E, ed), Springer-Verlag, Berlin, Germany, 1991, with permission; (C) U.S. Department of Energy Office of Science (http://www.jgi.doe.gov/sequencing/why/Treesei .html); (D) Sciencephoto.com; (E) courtesy of Ronald de Vries, CBS-KNAW, Fungal Biodiversity Centre, The Netherlands.

was present in the most active fractions and was highly expressed and secreted in all fungi that degraded lignocellulose $(\underline{43})$.

The enzyme responsible for such activity was first described as a glycohydrolase and was assigned to the protein family GH61 $(10, \underline{44})$. Further studies showed that this new GH61 type was widespread in the fungal kingdom, typically present in high numbers in the genome, and was not a GH enzyme but a monooxygenase $(45, \underline{46})$. As a consequence, such members of GH61 were recategorized as AA enzymes, were categorized as AA9, and were named LPMOs. Since the first article describing AA9 was published, knowledge of the LPMOs has grown explosively (47-49). Now several types of LPMOs are described under the following

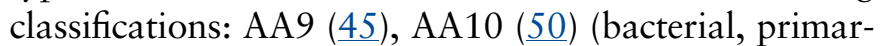
ily chitin degrading), AA11 (51, 52), and AA13 (53). Furthermore, LPMO activity has been described on substrates including starch ( $\underline{53})$, hemicellulose (54), and keratin (55). An interesting feature of genes encoding fungal LPMOs is that they are often found in very high numbers in the fungal genome (51). 
How Can Nature's Effective Fungal

\section{Lignocellulose Degraders Be Recognized?}

Fungal genome sequencing has shown that genes encoding cellulose- and hemicellulose-degrading enzymes are found in a very broad spectrum of fungi. However, many of such fungi may not necessarily functionally be effective biomass degraders, even though they have the spectrum of genes of relevance for lignocellulose decomposition.

The most efficient fungal lignocellulose degraders can often be recognized up-front by knowing their physiology and ecology: Does the species in nature always grow in habitats where biomass decomposition takes place? Is it a strong competitor on such substrates? Classical mycological expertise, such as knowledge about fungal habitats and substrate associations, can provide answers to such questions and is particularly relevant and valuable for developing more efficient biomass conversion processes. At the DNA level, genome sequencing gives information about whether the species in question has the full complement of cellulase and hemicellulase genes. However, to predict the potential of a fungal species, we need to know not just which families of enzyme genes are present on the genome but also for which enzyme function the genes code. Assigning genes to a given enzyme family is not enough to identify its function because most enzyme protein families include several types of function (7). Since gene sequences which are very distantly related may share the same function, blast searches and alignment are not sufficient to predict the function. Based on this analysis and reasoning, efforts were made to develop a new sequence analysis method which could more accurately predict function from sequence.

As a result, a new non-alignment-based sequence analysis method was invented (56); it was later developed into a versatile and fast peptide pattern recognition (PPR) technology platform (ㅁ, 10, 51, 57). PPR can identify short peptides which are conserved among enzymes with shared function. Based on this, groups of proteins with the same enzyme function can be identified. With this approach, enzyme discoveries can be made, mining sequence databases efficiently and predicting enzyme function directly from sequence.

\section{Different Mechanisms in the Fungal Breakdown of Cellulose}

The enzymatic breakdown of cellulose in nature follows three or four models (16, 58-61): (i) fungal enzymatic breakdown where enzymes with different functionalities (endoglucanase, CBHs, betaglucosidase, and LPMO) are produced by separate genes, which results in indi- vidual enzymes acting in synergy; (ii) cellulose breakdown, such as by brown rot fungi, where redox-acting enzymes give rise to ions needed for Fenton chemistry reactions to occur, which are capable even of breaking down the crystalline cellulose; and (iii) the bacterial model, where the genes needed for cellulose breakdown are placed sequentially in one reading frame and the proteins are placed in one huge molecular structure, the cellulosome, which processes the entire cascade of enzymatic reactions needed for breaking down cellulose; (iv) recently, a new category has been recognized, where enzyme hydrolysis is achieved by multimodular enzymes (viz., enzymes with multicatalytic domains [ 59, 62]). Such multimodular enzymes have been described and are expected to be found in more fungi degrading plant biomass. Recent studies also suggest that in some habitats, such as anaerobic environments, most of the secreted xylanolitic and cellulolytic enzymes are found as free enzymes and are not organized in cellulosomes; they are, however, to a large extent encoded by multimodular genes (Wilkens C, Busk P, Pilgaard B, Kirkegaard R, Albertsen M, Zhang W-J, Nielsen P, Lange L, in press).

Interestingly, fungal enzymatic breakdown of cellulose (category [i], above) follows very closely the bacterial enzymatic breakdown of chitin (viz., endo-acting chitinase plus reducing- and nonreducing-end, exoacting chitinases (50). Moreover, bacterial decomposition of chitin also involves LPMO activity-the bacterial AA10 family (45). The resemblance of cellulose decomposition by fungi to chitin decomposition by bacteria is remarkable in evolutionary terms.

Recently, a new mode of action of fungal enzymatic degradation of the proteinaceous polymer keratin has been described (64). Fungal breakdown of alpha keratin can involve three types of proteases: endo-acting, exoacting, and oligopeptide-acting (65); this pattern is thus also similar to fungal cellulose decomposition. Furthermore, keratin-degrading fungi (including the dermatophytes) also have LPMO genes (of type AA11) in their genomes (51). Such new knowledge could be applied to develop new technology for degrading chicken feathers and pig bristles, which so far are almost totally unexploited protein-rich waste.

\section{YEAST FERMENTATION: FROM SUGAR PLATFORM TO BIOETHANOL Fungal Yeasts: The System of Choice for Producing Bioethanol}

Yeast cultures have been used to produce ethanol since ancient times. Even after centuries of industrial and ac- 
ademic practice, development, and research, Saccharomyces cerevisiae is still the biological production system of choice. This yeast is easy to control in industrial settings, and the robustness of wild-type $S$. cerevisiae against the cell toxicity of ethanol is acceptable. Increased ethanol tolerance can also be achieved through strain development, by mutation, or by genetic modification.

The primary focus of most of the research to improve the efficiency of ethanol fermentation from the sugar platform has been on using a larger range of the sugars of the biomass or, more precisely, to improve yeast fermentation to exploit not only C6 sugars (cellulosederived glucose) but also C5 sugars (hemicellulosederived xylose). Some progress has been achieved (see below). Further progress may be achieved by following one of three approaches: (i) make bioethanol only from the cellulose C6 sugars and reserve the hemicellulose C5 monomer and oligo sugar for making higher-value products such as food or feed ingredients; (ii) improve the efficiency of ethanol-fermenting yeast strains for fermenting both C5 and C6 sugars to ethanol; or (iii) develop new fermentation systems that produce a new generation of biofuels (66).

Higher-value products from hemicellulose (C5) sugars can be achieved, for example, by producing food and feed ingredients, based on the complexity (branching and substitutions) of the native hemicellulose polymers. These products can be refined to even higher value by making food and feed ingredients that have healthpromoting effects such as prebiotic stimulation of the healthy gut flora of humans and nonruminant animals $(67,68)$. The resulting yeast biomass can also be upgraded to health-promoting ingredients, beta-glucans, nutraceuticals, or even drugs, based on the specialized fungal cell wall structure properties.

\section{Development of Improved Yeast Fermentation Strains}

In nature, yeast is primarily specialized to ferment C6 sugars. Until now, no wild-type microbe (yeast or bacteria) has been found which readily fulfills industrial demands such as efficient fermentation (high yields, rapid processing) of C5 sugars to ethanol and high tolerance to ethanol content in the fermentation broth.

Interesting attempts have been made to develop the bacterium Thermoanaerobacter mathranii (typical habitat is hot springs in North Atlantic areas) into an efficient ethanol production strain using both $\mathrm{C} 5$ and $\mathrm{C} 6$ sugars. High temperature tolerance makes recovery of the ethanol possible by skimming from the top of the fermentation culture, so the critical ethanol concen- tration detrimental to the production strain is never reached (69). So far, a similar approach for a thermophile yeast has not been developed.

Improved yeast strains have been developed by several small companies, for example, Terranol. An $S$. cerevisiae strain that efficiently ferments C5 sugars and yeast strains that also grow on and utilize glycerol were developed $(\underline{70}, 71)$. For such progress, the key genes to control were Gut1p (glycerol kinase) and Gut2p (mitochondrial glycerol-3-phosphate dehydrogenase) originating from $S$. cerevisiae $(\underline{72}, \underline{73})$. The next goal is to develop yeast strains capable of producing advanced biofuel (see below), as well as relevant chemical building blocks. The latter pave the way for renewable production of plant biomass-based chemicals, substituting for the current production of fossil-based chemicals. In the years to come the fuel- and chemical-producing organisms will be fungal, probably refined strains of $S$. cerevisiae (and in certain cases also strains of filamentous fungi), in versatile roles producing increased value from biomass. The core technology for this is enzymatic hydrolysis of the plant cell wall biomass, releasing free sugars from the plant polymers; this is followed by fermentation of fungi on the plant biomassderived sugar platform.

\section{BIOREFINERIES}

\section{Advanced Biofuels, Integrated Biorefineries, and On-Site Production of Enzymes}

The terminology around different types of biofuels is very confusing. There are not only first- and secondgeneration biofuel, but also third- and fourth-generation, and a clearly defined term is needed. The European Biofuel Technology Platform (http://biofuelstp.eu/) has suggested and defined "advanced biofuels" as the term of choice. Advanced biofuels are defined as (i) being produced from lignocellulosic feedstock (not directly from starch, lipid, or sugar), (ii) having low $\mathrm{CO}_{2}$ emission or high greenhouse gas reduction, and (iii) achieving zero or low indirect land use change impact.

Most of the advanced biofuels involve fungal enzymatic breakdown of biomass and fungal production of the advanced biofuel, but alternative systems are also being developed which do not involve fungi or fungal enzymes. These include advanced biofuels from algae or the use of physical and chemical processes, e.g., biodimethyl ether, biosynthetic natural gas, and bio-oil (75).

Integrated biorefineries (76) are not yet sufficiently cost-effective to be commercially viable. However, improved consolidated efficiency may be achieved by de- 
veloping fungal strains which can produce the enzymes needed for biomass conversion and also produce ethanol. Alternatively, fermentation conditions may be created which allow two types of fungi to work in parallel under conditions controlled by changes in $\mathrm{pH}$ or another flexible parameter.

Enzymes may be produced on-site (77) directly in the production plant. The required enzymes are, for example, produced on a side stream of the feedstock, and the entire content of the enzyme-producing seed tank is then added to the main tank to start the enzymatic biomass hydrolysis. Intellectual property and technology protection issues, restrictions on the use of genetically modified organism (GMO) strains in industrial-scale biorefineries, or suboptimized on-site enzyme blends for efficient biomass conversion have so far blocked such development. However, when biorefineries are developed in which several higher-value products are produced from the feedstock, efficiency may be measured in terms different from the current emphasis on quantification of free sugars.

\section{DISCOVERY AND PRODUCTION OF FUNGAL ENZYMES FOR BIOMASS CONVERSION \\ Production of Fungal Enzymes by Heterologous Expression in Fungal Production Hosts}

The most classic and impressive example of development of an enzyme production strain is the early industrial use of cellulases. The history of the development of Trichoderma into a production host for cellulases (16) highlights the application of mycological knowledge to solve an industrial problem and to contribute to more sustainable agroindustrial processing.

In general, the fungi chosen as expression and production hosts have primarily been filamentous ascomycetous species such as Trichoderma reesei (78), Aspergillus oryzae (79, $\underline{80})$, Aspergillus nidulans (1), and Aspergillus niger (2, $\underline{83}$ ). Efficient production strains of Fusarium venenatum have also been developed (84). Further, attempts have been made to develop Thermoascus aurantiacus into a production host for heterologously expressed genes of thermotolerant enzyme proteins ( $\underline{85})$. Yeasts have also been developed as production hosts, e.g., S. cerevisiae (6) and Pichia spp. (87), but in yeast the yield is in general significantly lower than what can be achieved with filamentous fungi. Yeasts are inferior with regard to protein secretion capabilities compared to filamentous fungi. This is an inherent characteristic of the yeast unicellular life form, with budding propagation and growth, because yeasts would not benefit from secreted enzymes that diffuse into the surrounding substrate. Figure 3 displays the five most prominent fungal species used in biomass conversion.

The company Dyadic has taken an interesting approach to the design of production hosts. Production strains of Myceliophthora thermophilum were developed in which the background of its native enzymes provided added value to the enzyme product; for instance, the native $M$. thermophilum cellulases boost the effect of the cellulases of a GMO construct $(M$. thermophilum with inserted cellulase genes, derived from other organisms) ( $\underline{88})$.

The latest significantly new type of application of GMO constructs of $T$. reese $i$ is that it is used as a production strain for producing not just one enzyme but blends of recombinantly produced plant biomassconverting enzymes (e.g., Novozymes CellicCTec3: http:// www.bioenergy.novozymes.com/en/cellulosic-ethanol /CellicCTec3/Pages/default.aspx) (90-92). Several genes are inserted into the genome, and the fermentation is developed to give an optimized blend, designed for efficient biomass conversion. It is noteworthy that for blends, most of the cellulase genes of Trichoderma have been replaced with superior cell wall-degrading enzymes from other fungi. Thus, the unique capability of Trichoderma to produce and secrete enzymes, and not the qualities of the Trichoderma enzymes, make this fungus the system of choice for biomass blend production.

Yeast production of industrial enzymes in bulk is still only barely commercially viable at a large scale, even though fermentation technologies leading to high yeast cell density (93) have to a certain degree compensated for the lower yield. However, at the laboratory scale, heterologous expression systems based on Pichia spp. and $S$. cerevisiae are commonly used as the system of choice for production and characterization of novel eukaryote proteins. The low level of glycosylation that takes place in these expression host systems can, however, be a drawback (7).

Interestingly, Ascomycetes spp., for instance, Trichoderma spp. and Aspergillus spp., also function well as production hosts for a broad spectrum of enzyme genes derived from other parts of the fungal kingdom (from species of Basidiomycota, Zygomycota, and even Chytridiomycota). However, production, for example, of basidiomycete genes in ascomycetous hosts may still result in lower yields compared to ascomyceteous genes (94). Codon-optimized synthetic genes may solve or at least minimize this problem. 
Fungal Enzymes and Yeasts for Conversion of Plant Biomass

Plant enzymes that also are of importance for biomass conversion have proven difficult to produce in filamentous fungi. Interestingly, the only effective expression of plant enzymes in fungi has been in yeasts and not in filamentous species $(95,96)$. Studies have been conducted to understand why successful expression of plant enzymes in filamentous fungi is blocked. Hamann and Lange found that filamentous fungal expression strains of $A$. oryzae misread the sequence of the plant enzyme gene as splicing sites, leading to production of fractionated mRNA and therefore to the lack of production of functional plant proteins (97).

Details about how to construct the most efficient fungal production hosts and which level of yield is achievable are primarily found in patent literature (giving a basis for the patent claims) or are more commonly kept as company-confidential. To be competitive in the industrial biotech industry, it is essential to have a very cost-efficient and cost-competitive enzyme production and enzyme recovery system, and the relevant details are considered strictly confidential.

An important part of developing a production host system is to modify the production strain by deletion of genes. Modifications may include abolishing end product inhibition and knocking out protease genes, which may break down the enzyme protein produced, and finally also to knock out the background of secreted enzymes which may interfere with the final enzyme product.

Another important issue is to have the fungal production strain approved by regulatory authorities, preferentially as a GRAS (generally recognized as safe) organism (98). This is needed for approval of the production plant and production process and is of special importance if food-grade enzymes are to be produced.

\section{Fungi as Gene Donors: Discovery of New Industrially Relevant Fungal Enzymes}

The technologies used for the discovery of new and improved fungal (and bacterial) enzymes have undergone significant development since the start of large-scale commercialization of microbial enzymes. The knowledge and experience gained during the different stages of industrial biotech are also relevant to future development of the bioeconomy. Several chapters of the new segment of industrial biotech (the circular bioeconomy, where local bioresources such as crop residues and agroindustrial side streams are upgraded to higher value in nearby biorefineries) lie ahead: big biorefineries will be supplemented by smaller, decentralized and specialized use of bioprocessing; the need for new blends of enzymes for conversion of new types of complex biomass will grow. The use of microbial consortia may, in special instances, supplement the current pure culture fermentations, and new types of enzymes will be needed and new mechanisms of biocatalysis synergy may be discovered. This development will involve the increased use of a diversity of fungal (and bacterial) enzymes.

The inspiration for such development will be through a technology push, where new methods pave the way for new solutions. Likewise, studies of nature's own biomass conversion will also inspire and drive discoveries. Combining the two could prove to be a powerful strategy. Such developments inherently imply that discovery technologies should also be modified and developed to function efficiently at the metagenomics and metatranscriptomics level, including the unculturable part of the microbiomes (99).

\section{Enzyme Discovery from Nature}

From the start of the industrial use of enzymes, the goal of discovery of fungal enzymes has been to find fungal isolates with a high level of activity on relevant defined or complex substrates. The enzyme protein should be stable and have $\mathrm{pH}$ and temperature profiles that match industrial process conditions. By this approach the discovery is based on experimental laboratory evaluation of the fungal strain and its enzymes, handling as one sample the entire multienzyme culture broth, with enzyme concentrations given by the fermentation physiology. Such screening and evaluation conditions favor the discovery of enzymes produced in high concentrations by their wild-type fungus and preferentially detect enzymes with good stability and high specific activity. However, with this approach it is easy to overlook enzymes for which no assays have been developed or cases in which several enzymes are needed from more than one organism (100).

A large spectrum of enzyme products relevant for industrial biotechnology was developed in the 1960s, 1970 s, and first half of the 1980s based on such an enzyme discovery strategy. The strategy tapped into the microbial diversity available from culture collections and from the pool of naturally occurring microorganisms. Two examples are amylases for the detergent industry (bacterial, e.g., from Bacillus spp.) and cellulases for the textile industry (fungal, e.g., from Trichoderma spp. [101]). These examples relate to two very different industrial processes: (i) high $\mathrm{pH}$ and specific temperature stability and activity requirements and (ii) low $\mathrm{pH}$ and a broad spectrum of acceptable temperature activity profiles. 
Exploitation of the early cellulase enzyme discoveries depended on more than the activity of the enzyme. The native fungal producer needed to grow well under submerged, aerated, fermentation conditions and to produce a good yield of the enzyme protein under such conditions. Basically, developing enzyme manufacturing systems with low production and recovery costs laid the foundation for industrial biotechnology. A realistic value proposition could be presented, which could convince industrial decision makers that biological processing could compete with chemical processing in cost, as well as in robustness and performance. The new biological processing also meant changing to a sustainable process technology, with less polluting chemicals in the wastewater and less energy use for high pressure and high temperature used in chemical processing. The emerging development of such competitive biological processing that was able to replace chemical processing (102) opened the way for setting environmental requirements to obtain regulatory approval of production facilities. This in turn meant that new environmental standards could be set, drawing up limits for acceptable negative impacts on the environment. The third type of driver for the development of gentle and competitive biological processing was to make improved use of the raw material, i.e., to obtain more product from the same raw material. Fungal cellulases were developed for treatment of, for example, fruit pulp after initial juice processing. A cellulase treatment could result in significantly higher yield of juice (and wine) simply by breaking down more of the plant cell walls to allow more juice to be extracted (103).

Next, the textile industry needed an enzyme for stone washing of jeans (104) and enzymes for the detergent industry for more gentle, color-protecting washing powder (105). Both of these commercial targets facilitated investments in significant $R \& D$ efforts to find new and interesting fungal cellulases. An important discovery was the GH45 protein, produced by the thermophilic fungus Humicola insolens (Ascomycota, Sordariales) (106). The enzymes of $H$. insolens are active at rather high $\mathrm{pH}(\mathrm{pH} 8)$ and stable at elevated temperatures, with the maximum at $\mathrm{ca} .45^{\circ} \mathrm{C}(104,105)$.

During this period the foundation was laid for developing biocatalysis to replace many of the previously chemistry-based processes. But in the following period, the 1980s and 1990s, huge steps were taken to build the basis for understanding the complexity of plant cell wall-degrading enzymes. This knowledge was later used to develop the blend of cellulases needed for converting lignocellulosic biomass into biofuel $(\underline{89}, \underline{106})$.

\section{Monocomponent Enzymes Produced by Fungal GMO Production Strains}

Analysis of the efficiency of enzyme production, e.g., productivity per tank year or enzyme yield per liter of fungal culture broth produced, revealed that much of the production capacity of the fungus and of the fermentation tanks was used to produce enzymes which did not add direct value for the customers (107).

Around the same time, in the 1980s, GMO technology was in its infancy, primarily focusing on making GMO constructs of plant cultivars (108) and in Escherichia coli $(109,110)$. From this research it became apparent that both prokaryote and eukaryote cells were able to produce much higher yields of single proteins than had been observed in wild-type strains. The use of a range of different promoters and of methods for selection of the highest-yielding transformants also inspired further development of microbial industrial biotechnology.

In 1988 the first GMO strain of an industrial enzyme was produced. It was a recombinant, monocomponent lipase enzyme for the detergent industry, expressed in A. oryzae (111). It was produced in Novo's facility in Japan because Danish legislation for industrial handling of GMO strains was not yet developed (112). This success inspired a new strategy among the leading industrial biotechnology companies (Novo and Danisco in Denmark, DSM in The Netherlands, and Genencore in the United States). Dialogue with, e.g., the Danish Environmental Protection Agency authorities (http:// eng.mst.dk/) was very constructive, and both industry and authorities wanted strict regulation. Many years later, this proved to be a very wise decision. The strict requirements and regulatory conditions for approval of GMO strains and GMO production facilities, processes, and products laid the foundation for public acceptance of this new technology. The production vehicle was GMO-based but biologically confined to the fermentation plant, with no living GMO present in the end product and therefore no GMO organism reaching the end user. A new era of industrial biotechnology had begun.

\section{Discovery and Optimization of Genes for Production of Monocomponent Enzymes}

The initial step was finding a fungus with enzyme activities of interest and the necessary protein stability under industrially relevant $\mathrm{pH}$ and temperature conditions. This step was the same as for discovery of the classical non-GMO enzymes. But after this initial step, the entire discovery process was radically different. The 
first attempts to separate the wanted enzyme out of the complexity of the culture broth were tedious, costly, and slow; even if successful, discovery of the specific gene which could be inserted in the production host was far from easy. After a promising fungal isolate with interesting enzyme characteristics had been identified, the obvious next step was to focus on the genes, not the protein, and a strategy was developed as follows: (i) isolate the mRNA (which as a pool represents all expressed proteins), (ii) use this pool of mRNA to identify the cDNA of interest, and then (iii) insert this cDNA into the (heterologue expression) production host. By using cDNA, the uncertainty about whether the heterologue expression host could cope with the splicing of a foreign gene was circumvented, because cDNA has no introns. Only the coding part of the reading frame is transformed into the production host (100).

The next step was to efficiently develop (and screen) high-quality cDNA libraries to identify specific enzyme activities of interest. This process was developed to perfection in industry. During this period cDNA library screening became the single most used molecular technology in enzyme discovery, and it has resulted in the vast majority of new fungal enzyme discoveries commercialized over a period of 10 to 20 years. To date, a major proportion of commercially available fungal industrial enzymes have been found by cDNA screening technology (100).

The principles of high-throughput fungal cDNA technology screening (114) are as follows. (i) Prepare fungal biomass which has been exposed to the substrate components of relevance for the enzymes of interest. This is usually done by growing the selected fungal strain on its native substrate or on a well-defined medium containing the substrate of relevance for the enzyme activity of interest. (ii) Prepare total RNA followed by a polyA (tail) column separation of the mRNA fraction of the total RNA. (iii) Make the cDNA on the basis of the mRNA. (iv) Insert the cDNA in an E. coli library for propagation of the $\mathrm{CDNA}$. (v) Insert the cDNA in a yeast expression host. For this, an $S$. cerevisiae strain was chosen with very limited background enzyme activity, and a substrate-induced promoter was included which only opened for gene expression if galactose was present in the growth media. The resulting yeast cDNA library was then screened for activity on multiple substrates by replica plating. Stock cultures and plates were maintained without promoter-inducing galactose to avoid fatigue of the selected transformants with promoter turned on all time. Such series of transformants were screened by measuring the activity obtained in small- scale fermentation, leading to selection of the transformants with the highest yield. The result of such cDNA screening $(100)$ was a yeast clone harboring the gene of interest that was known to be expressed and secreted; the gene found was full length and gave rise to a secreted, functional protein with the relevant activity.

The patent strategy for enzyme discovery and for product and process technology protection improved dramatically, along with development of monocomponent enzymes, GMO production strains and production processes, and value-added, end-product uses. It was of particular interest to extend the product patent coverage, which provided a basis for and resulted in protection significantly broader than just for the enzyme found. As a consequence, with patent protection as a driver, a series of new technologies were developed. These included approaches for the identification of conserved areas of the genes of interest to construct primers for PCR screening, thereby allowing for the discovery of nature's variants of the same gene $(115)$. Patent examples based on such discoveries were a basis for broader claims of variation in sequence identity and for patent claims covering immunological recognition. One of the largest such efforts is Novozyme's GH45 patent claiming nature's variants of the GH45 gene across all fungal kingdom phyla (116).

\section{Protein Engineering to Improve Enzymes for Conversion of Plant Materials}

Three significant activities led to the development of molecular biotechnology R\&D as a prominent field in its own right: (i) discovery of monocomponent protein backbones, (ii) sequencing of the enzyme proteins discovered becoming accessible and affordable, and (iii) elucidation of three-dimensional enzyme protein structures. Protein engineering (PE) became a scientific discipline and an important part of industrial biotech R\&D. Both random mutagenesis and targeted mutagenesis were applied with a high level of success. The efficiency of particular enzymes with robust activity could be significantly improved through random or targeted mutation schemes to modify the optimum $\mathrm{pH}$ and temperature to match industrial needs. Another target of protein engineering was to change enzyme stability and robustness toward chemical and biochemical process agents. Generally, PE developed into a complex operation in which many rounds of different technologies eventually were merged together in one process, named artificial evolution. Along with such methodological progress, the use of high-throughput, automated laboratory screening by robotics was devel- 
oped to build on not just smartness in thinking but also number-crunching power as a basis for selection of the superior enzyme activity (117-119).

A dedicated nonevolutionary technology—shuffling technology (viz., cutting the gene to pieces, shuffling the gene parts, and reassembling them into new sequences) -was also developed as part of the artificial evolution. This was the basis for improving function to a level hitherto not achievable through mutations and selection $(120,121)$.

Protein engineering R\&D efforts became so successful that for a period it appeared that discovery of new wildtype enzymes from nature's diversity might not be needed in the future. The diversity needed to satisfy industrial needs and end user demands was predicted to be met by engineering already known protein DNA backbones. However, it became apparent that finding activities radically different from known enzymes was most efficiently achieved by screening wild-type microorganisms and then using PE to optimize on such a backbone.

\section{Next-Generation Sequencing Revolutionized Enzyme Discovery}

The next-generation sequencing technologies paved the way for a new generation of microbial discovery strategies $(63,122)$. Initially, the technology was a shortcut to the integrated use of sequencing of, e.g., PCR bands identified in PCR screening searching for more variants of a lead enzyme gene, and for dynamic and fast sequencing of the new genes discovered by, e.g., cDNA screening to allow fast and efficient priority patenting. In short, the new-generation sequencing technology became a game changer: sequencing was much faster, prices dropped, and sequencing capacity, availability, and accessibility increased. Whole-genome sequencing became part of a standard enzyme protein discovery procedure which generated new sequences and mined sequences which had been placed in the public domain by other scientists with insufficient knowledge of the enzymes coded for by such deposited genes. Efficient enzyme discovery was now de facto tripartite: (i) discovery of new wild-type enzyme backbones from nature's diversity, (ii) discovery from man-made diversity (PE variant and mutagenesis libraries), and (iii) discovery by in silico mining of deposited sequences. The three approaches could strategically be placed sequentially: identifying interesting organisms by determining interesting habitats and by activity profiling such organisms, sequencing the genome of the selected organisms, and mining the new genomes along with other related ge- nomes and genes and selecting the most promising genes for expression for further characterization of the enzyme protein. If gene expression was successful and the protein had promising activities, automated screening of variant libraries would generate fast and improved versions of the new enzyme.

The limiting factor and pitfall for such new, sequencebased enzyme discovery is 2 -fold. There may be a rather high risk of unsuccessful expression of the selected gene, and the limited number of available enzyme activity assays fails to precisely detect the desired novel type of activity.

Two new types of technologies, TAST and PPR, were developed to optimize exploitation of the overwhelming amount of sequence data available from new-generation sequencing of both eukaryote and prokaryote organisms $(\underline{42}, \underline{74})$. Both technologies aimed at optimizing the possibilities of finding novel and improved types of enzyme activities from enzymes which are also expressed as functional proteins in nature, therefore with optimized perspectives for good expression in industrial production hosts.

The basic principle of TAST (42) is reflected in the construction of the transposon: a $\beta$-lactamase gene without its signal peptide is inserted (together with other marker genes) into the transposon. When a new gene is inserted in the E. coli screening host along with the transposon, the transformant cell, when screened on ampicillin-holding plates, will survive only if the gene has a signal peptide. This is because the $\beta$-lactamase protein is transported across the cell membrane and therefore correctly folded only if the $\beta$-lactamase gene on the transposon is fused with a signal peptide (from the new enzyme gene), making the $\beta$-lactamase active and thus protecting the transformant cell against ampicillin. Surprisingly, TAST screening could be used for discovery of novel genes and proteins from all groups of prokaryotes and eukaryotes even though the determining screening criterion is transportation over the E. coli cytoplasmic membrane. Enzymes with totally novel enzyme sequences and enzymes for which we did not have any assays available could now be found by TAST (42, 97).

A convincing example of the significance of the new TAST technology was the discovery of a new type of enzyme (GH61), which was found as being expressed in high numbers in almost all TAST screening projects performed with cellulose- and lignocellulose-degrading fungi (43). GH61 (now known as LPMO, AA9) is now a standard component of commercialized plant biomassdegrading enzyme blends. 
TAST, however, was not an easy technology to exploit. Most laboratories which tried it did not succeed. New and improved methods were needed for finding secreted enzymes. Further, a need arose for making it possible to find also the sequence commonality among even distantly related proteins sharing the same function. Based on this, a new protein discovery technology, PPR, was invented.

PPR is a non-alignment-based, sequence analysis method which identifies conserved n-mer peptides and enables the assembling of a group of proteins sharing more than a set number of conserved peptides from a given list (56). Such PPR groupings have been validated to correlate to the enzyme function (10) and can be used (through application of additional PPR technology platform software programs) to predict function directly from sequence (9). PPR is faster and more efficient than other methods in mining even very large data sets. PPR can also be used to efficiently mine huge databases of metagenomic as well as metatranscriptomic sequences.

PPR enables discoveries of functions where screening assays have not been developed and facilitates the discovery of sequences of very distantly related genes with low shared sequence identity but the same function. It is currently superior to other sequencing analysis methodologies because it predicts the function directly from the sequence, which is especially valuable if discoveries are sought from microorganisms or habitats where annotated genome sequencing is not available. PPR can also be used efficiently to find new discoveries from poorly annotated sequence databases and to find more members of described families than have been found before (leading to in silico expansion of protein families). PPR brings order out of chaos.

The low cost of synthetic genes-codon optimized to the expression system of choice (for fungal genes, e.g., Pichia pastoris) - has made in silico discoveries (combined with PPR sequence analysis) a shortcut to the discovery of novel enzymes, e.g., for efficient conversion of new types of feedstocks.

\section{FUTURE PERSPECTIVES: UPGRADING MORE ORGANIC FEEDSTOCKS TO EVEN HIGHER VALUE AND NEW BUSINESS MODELS}

Exploitation of enzymes for the bioeconomy upgrade of complex organic residues, by-products, and waste streams has ushered in a new era of biological production. Earlier, monocomponent enzymes produced in GMO production hosts were commercialized following the business model of one gene, one enzyme, one product. However, the new production technology and business model for biomass conversion enzymes builds on several different genes transformed into one and the same production strain (for example, T. reesei), leading to production of a designed composite blend of enzymes $(\underline{89}, 90)$.

The next steps are to design enzyme blends for processing of more types of biomass, such as new types of plant feedstocks and agroindustrial by-products, biomass of fungi (e.g., vinasse, the spent microbial biomass from biorefineries), and of macroalgae (primarily brown and red), as well as to develop upscaled methods for valorization of organic fractions of household waste and sludge. The focus will broaden from being confined to the breakdown to monomer sugars to include recovery of selected structural components of the biomass for highervalue products (e.g., health-promoting prebiotics).

Systems for "on-site production" of enzymes may also be developed, for example, by growing fungi that produce blends of enzymes directly on the organic fraction of household waste and using this enzyme blend for hydrolysis and liquefaction of the organic part of the mixed waste stream. Development of hydrolysis and liquefaction processing of organic household waste has already been accomplished (see http://www.renescience .com/en). Similarly, fungal starter cultures could be developed for direct "on-farm" upgrade of crop residues (e.g., from vegetable production) to a protein-rich and bioaccessible animal feed.

Another future approach is to promote the use of fungal enzymes and fungal starter cultures in developing countries at the village level for upgrading organic waste to fuel, feed, and fertilizer. Such decentralized use of enzymatic biomass conversion could be promoted further if local scientists, mycologists, agronomists, and plant pathologists could more readily access the cultures and the knowledge of biomass conversion. A vision has been formulated for an open access biology (1) administered by international culture collections, where the essential strains and knowledge could be accessed. Strains earmarked for open access biology should be safe, efficient production hosts, gene donors, or starter cultures that are available in the public domain with freedom to operate royalty free.

\section{MYCOLOGICAL PERSPECTIVES: FUNGAL SECRETOME, EVOLUTION, AND DYNAMICS}

The enzyme composition of the secretome of filamentous fungi provides a basis for efficient biomass conversion and valorization. More research into the evolution and dynamics of the fungal secretome, put in 
evolutionary perspective, is essential for understanding biomass conversion in nature and for developing biomass conversion even further. In nature, evolutionary pressure is on the secretome and on the enzyme functions, proteins, and genes, because increased fitness is achieved through efficient enzymatic breakdown of available organic materials $(\underline{89}, \underline{113})$. The mechanisms for adaptation of fungal secretome composition and enzyme functions are gene copying, followed by gene loss or gene retention, similar to the process of speciation, but faster. Evidence is growing of the prevalence of an additional mechanism: horizontal gene transfer. This occurs in special habitats such as cow rumen and gut channels but is expected to be found more widely among fungal habitats, including other biomass conversion hot spots. Studies of such habitats can pave the way for interesting, new conceptual understandings of relevance for both mycology and applied use.

The fungal gardens of termites and leaf cutter ants can be seen as nature's prototype for the yellow and the green biorefineries (28). In the garden, fungal biomass is used to feed entire colonies. Similarly, new higher-value products derived from fungal biomass could be the next important new step in the bioeconomy for improving the health of both humans and livestock (ㅎ8).

\section{REFERENCES}

1. Lange L. 2014. The importance of fungi and mycology for addressing major global challenges. IMA Fungus 5:463-471 http://dx.doi.org/10.5598 limafungus.2014.05.02.10.

2. Food and Agriculture Organization of the United Nations. 2016. FAO Food Loss and Food Waste. http://www.fao.org/food-loss-and-food -waste/en/.

3. Lange L, Björnsdottir B, Brandt A, Hildén K, Hreggviðsson G, Jacobsen B, Jessen A, Karlsson EN, Lindedam J, Mäkelä M, Smáradóttir S, Vang J, Wentzel A. 2016. Development of the Nordic Bioeconomy: NCM Reporting: TEST Centers for Green Energy Solutions - Biorefineries and Business Needs. Nordisk Ministerråd, Copenhagen, Denmark.

4. Schmid O, Padel S, Levidow L. 2012. The bio-economy concept and knowledge base in a public goods and farmer perspective. Bio-based Appl Econ 1:47-63.

5. Kubicek CP, Starr TL, Glass NL. 2014. Plant cell wall-degrading enzymes and their secretion in plant-pathogenic fungi. Annu Rev Phytopathol 52:427-451 http://dx.doi.org/10.1146/annurev-phyto-102313-045831.

6. Harris SD, Read ND, Roberson RW, Shaw B, Seiler S, Plamann M, Momany M. 2005. Polarisome meets spitzenkörper: microscopy, genetics, and genomics converge. Eukaryot Cell 4:225-229 http://dx.doi.org 110.1128/EC.4.2.225-229.2005.

7. CAZy. 2016. The CAZy database. http://www.cazy.org/.

8. Lange L, Pilgaard B, Gleason F, Busk PK, Gorm-Pedersen A. 2015. The chytrid secretome: a comparative analysis of the secretome of an aerobic, anaerobic and pathogenic Chytrid species. Poster, 28th Fungal Genetics Conference, Pacific Grove, CA.

9. Busk PK, Lange M, Pilgaard B, Lange L. 2014. Several genes encoding enzymes with the same activity are necessary for aerobic fungal degradation of cellulose in nature. PLoS One 9:e114138. http://dx.doi.org 110.1371/journal.pone.0114138.
10. Busk PK, Lange L. 2013. Function-based classification of carbohydrate-active enzymes by recognition of short, conserved peptide motifs. Appl Environ Microbiol 79:3380-3391 http://dx.doi.org/10.1128/AEM $.03803-12$.

11. Hansen GH, Lübeck M, Frisvad JC, Lübeck PS, Andersen B. 2015. Production of cellulolytic enzymes from ascomycetes: comparison of solid state and submerged fermentation. Process Biochem 50:1327-1341 http:// dx.doi.org/10.1016/j.procbio.2015.05.017.

12. Gostinčar C, Ohm RA, Kogej T, Sonjak S, Turk M, Zajc J, Zalar P, Grube M, Sun H, Han J, Sharma A, Chiniquy J, Ngan CY, Lipzen A, Barry K, Grigoriev IV, Gunde-Cimerman N. 2014. Genome sequencing of four Aureobasidium pullulans varieties: biotechnological potential, stress tolerance, and description of new species. BMC Genomics 15:549. http:// dx.doi.org/10.1186/1471-2164-15-549.

13. Rineau F, Roth D, Shah F, Smits M, Johansson T, Canbäck B, Olsen PB, Persson P, Grell MN, Lindquist E, Grigoriev IV, Lange L, Tunlid A. 2012. The ectomycorrhizal fungus Paxillus involutus converts organic matter in plant litter using a trimmed brown-rot mechanism involving Fenton chemistry. Environ Microbiol 14:1477-1487 http://dx.doi.org /10.1111/j.1462-2920.2012.02736.x.

14. Poidevin L, Berrin JG, Bennati-Granier C, Levasseur A, HerpoëlGimbert I, Chevret D, Coutinho PM, Henrissat B, Heiss-Blanquet S, Record E. 2014. Comparative analyses of Podospora anserina secretomes reveal a large array of lignocellulose-active enzymes. Appl Microbiol Biotechnol 98:7457-7469 http://dx.doi.org/10.1007/s00253-014-5698-3.

15. Poidevin L, Feliu J, Doan A, Berrin JG, Bey M, Coutinho PM, Henrissat B, Record E, Heiss-Blanquet S. 2013. Insights into exo- and endoglucanase activities of family 6 glycoside hydrolases from Podospora anserina. Appl Environ Microbiol 79:4220-4229 http://dx.doi.org 110.1128/AEM.00327-13.

16. Payne CM, Knott BC, Mayes HB, Hansson H, Himmel ME, Sandgren M, Ståhlberg J, Beckham GT. 2015. Fungal cellulases. Chem Rev 115:1308-1448 http://dx.doi.org/10.1021/cr500351c.

17. Pollegioni L, Tonin F, Rosini E. 2015. Lignin-degrading enzymes. FEBS J 282:1190-1213 http://dx.doi.org/10.1111/febs.13224.

18. Kern M, McGeehan JE, Streeter SD, Martin RNA, Besser K, Elias L, Eborall W, Malyon GP, Payne CM, Himmel ME, Schnorr K, Beckham GT, Cragg SM, Bruce NC, McQueen-Mason SJ. 2013. Structural characterization of a unique marine animal family 7 cellobiohydrolase suggests a mechanism of cellulase salt tolerance. Proc Natl Acad Sci USA 110:10189-10194 http://dx.doi.org/10.1073/pnas.1301502110.

19. Cosgrove DJ. 2000. Loosening of plant cell walls by expansins. Nature 407:321-326 http://dx.doi.org/10.1038/35030000.

20. Cosgrove DJ, Li LC, Cho HT, Hoffmann-Benning S, Moore RC, Blecker D. 2002. The growing world of expansins. Plant Cell Physiol 43:1436-1444 http://dx.doi.org/10.1093/pcp/pcf180.

21. Brotman Y, Briff E, Viterbo A, Chet I. 2008. Role of swollenin, an expansin-like protein from Trichoderma, in plant root colonization. Plant Physiol 147:779-789 http://dx.doi.org/10.1104/pp.108.116293.

22. Lange M, Hora FB. 1963. Collins' Guide to Mushrooms and Toadstools. Collins, London, United Kingdom.

23. Berka RM, Grigoriev IV, Otillar R, Salamov A, Grimwood J, Reid I, Ishmael N, John T, Darmond C, Moisan M-C, Henrissat B, Coutinho PM, Lombard V, Natvig DO, Lindquist E, Schmutz J, Lucas S, Harris P, Powlowski J, Bellemare A, Taylor D, Butler G, de Vries RP, Allijn IE, van den Brink J, Ushinsky S, Storms R, Powell AJ, Paulsen IT, Elbourne LDH, Baker SE, Magnuson J, Laboissiere S, Clutterbuck AJ, Martinez D, Wogulis M, de Leon AL, Rey MW, Tsang A. 2011. Comparative genomic analysis of the thermophilic biomass-degrading fungi Myceliophthora thermophila and Thielavia terrestris. Nat Biotechnol 29:922-927 http:// dx.doi.org/10.1038/nbt.1976.

24. Cragg SM, Beckham GT, Bruce NC, Bugg TDH, Distel DL, Dupree P, Etxabe AG, Goodell BS, Jellison J, McGeehan JE, McQueen-Mason SJ, Schnorr K, Walton PH, Watts JEM, Zimmer M. 2015. Lignocellulose 
degradation mechanisms across the tree of life. Curr Opin Chem Biol 29:108-119 http://dx.doi.org/10.1016/j.cbpa.2015.10.018.

25. Brune A. 2014. Symbiotic digestion of lignocellulose in termite guts. Nat Rev Microbiol 12:168-180 http://dx.doi.org/10.1038/nrmicro3182. 26. Ni J, Tokuda G. 2013. Lignocellulose-degrading enzymes from termites and their symbiotic microbiota. Biotechnol Adv 31:838-850 http://dx.doi.org/10.1016/j.biotechadv.2013.04.005.

27. Watanabe H, Tokuda G. 2010. Cellulolytic systems in insects. Annu Rev Entomol 55:609-632 http://dx.doi.org/10.1146/annurev-ento-112408 $\underline{-085319 .}$.

28. Lange L, Grell MN. 2014. The prominent role of fungi and fungal enzymes in the ant-fungus biomass conversion symbiosis. Appl Microbiol Biotechnol 98:4839-4851 http://dx.doi.org/10.1007/s00253-014 -5708-5.

29. Huang Y, Busk PK, Grell MN, Zhao H, Lange L. 2014. Identification of a $\beta$-glucosidase from the Mucor circinelloides genome by peptide pattern recognition. Enzyme Microb Technol 67:47-52 http://dx.doi.org /10.1016/j.enzmictec.2014.09.002.

30. Taylor CB, Talib MF, McCabe C, Bu L, Adney WS, Himmel ME, Crowley MF, Beckham GT. 2012. Computational investigation of glycosylation effects on a family 1 carbohydrate-binding module. J Biol Chem 287:3147-3155 http://dx.doi.org/10.1074/jbc.M111.270389.

31. Lombard V, Golaconda Ramulu H, Drula E, Coutinho PM, Henrissat B. 2014. The carbohydrate-active enzymes database (CAZy) in 2013. Nucleic Acids Res 42(D1):D490-D495 http://dx.doi.org/10.1093/nar/gkt1178.

32. Bech L, Busk PK, Lange L. 2014. Cell wall degrading enzymes in Trichoderma asperellum grown on wheat bran. Fungal Genomics Biol 4:116. doi:10.4172/2165-8056.1000116.

33. Dotsenko G, Tong X, Pilgaard B, Busk PK, Lange L. 2016. Acidicalkaline ferulic acid esterase from Chaetomium thermophilum var. dissitum: molecular cloning and characterization of recombinant enzyme expressed in Pichia pastoris. Biocatal Agric Biotechnol 5:48-55.

34. Huang Y, Busk PK, Lange L. 2015. Cellulose and hemicellulosedegrading enzymes in Fusarium commune transcriptome and functional characterization of three identified xylanases. Enzyme Microb Technol 73-74:9-19 http://dx.doi.org/10.1016/j.enzmictec.2015.03.001.

35. Tong X, Lange L, Grell MN, Busk PK. 2015. Hydrolysis of wheat arabinoxylan by two acetyl xylan esterases from Chaetomium thermophilum. Appl Biochem Biotechnol 175:1139-1152 http://dx.doi.org/10.1007 Is12010-014-1348-6.

36. Várnai A, Huikko L, Pere J, Siika-Aho M, Viikari L. 2011. Synergistic action of xylanase and mannanase improves the total hydrolysis of softwood. Bioresour Technol 102:9096-9104 http://dx.doi.org/10.1016 /j.biortech.2011.06.059.

37. Dutta S, Wu KC. 2014. Enzymatic breakdown of biomass: enzyme active sites, immobilization, and biofuel production. Green Chem 16: 4615-4626 http://dx.doi.org/10.1039/C4GC01405G.

38. Riley R, Salamov AA, Brown DW, Nagy LG, Floudas D, Held BW, Levasseur A, Lombard V, Morin E, Otillar R, Lindquist EA, Sun H, LaButti KM, Schmutz J, Jabbour D, Luo H, Baker SE, Pisabarro AG, Walton JD, Blanchette RA, Henrissat B, Martin F, Cullen D, Hibbett DS, Grigoriev IV. 2014. Extensive sampling of basidiomycete genomes demonstrates inadequacy of the white-rot/brown-rot paradigm for wood decay fungi. Proc Natl Acad Sci USA 111:9923-9928 http://dx.doi.org /10.1073/pnas.1400592111. (Erratum, 111:14959.)

39. Fernandez-Fueyo E, et al. 2012. Comparative genomics of Ceriporiopsis subvermispora and Phanerochaete chrysosporium provide insight into selective ligninolysis. Proc Natl Acad Sci USA 109:5458-5463 http://dx.doi.org/10.1073/pnas.1119912109.

40. Ruiz-Dueñas FJ, Lundell T, Floudas D, Nagy LG, Barrasa JM, Hibbett DS, Martínez AT. 2013. Lignin-degrading peroxidases in Polyporales: an evolutionary survey based on 10 sequenced genomes. Mycologia 105:1428-1444 http://dx.doi.org/10.3852/13-059.
41. Kudanga T, Le Roes-Hill M. 2014. Laccase applications in biofuels production: current status and future prospects. Appl Microbiol Biotechnol 98:6525-6542 http://dx.doi.org/10.1007/s00253-014-5810-8.

42. Becker F, Schnorr K, Wilting R, Tolstrup N, Bendtsen JD, Olsen PB. 2004. Development of in vitro transposon assisted signal sequence trapping and its use in screening Bacillus halodurans C125 and Sulfolobus solfataricus P2 gene libraries. J Microbiol Methods 57:123-133 http://dx .doi.org/10.1016/j.mimet.2003.12.002.

43. Schnorr KM, Landvik S, Spendler T, Christensen LLH. April 2004. Family gh 61 polypeptides. European patent WO2004031378A2.

44. Harris PV, Welner D, McFarland KC, Re E, Navarro Poulsen JC, Brown K, Salbo R, Ding H, Vlasenko E, Merino S, Xu F, Cherry J, Larsen S, Lo Leggio L. 2010. Stimulation of lignocellulosic biomass hydrolysis by proteins of glycoside hydrolase family 61: structure and function of a large, enigmatic family. Biochemistry 49:3305-3316 http://dx.doi.org /10.1021/bi100009p.

45. Vaaje-Kolstad G. 2010. An oxidative enzyme boosting the enzymatic conversion of recalcitrant polysaccharides. Science 330:219-222.

46. Horn SJ, Vaaje-Kolstad G, Westereng B, Eijsink VG. 2012. Novel enzymes for the degradation of cellulose. Biotechnol Biofuels 5:45 http:// dx.doi.org/10.1186/1754-6834-5-45.

47. Beeson WT, Vu VV, Span EA, Phillips CM, Marletta MA. 2015. Cellulose degradation by polysaccharide monooxygenases. Annu Rev Biochem 84:923-946 http://dx.doi.org/10.1146/annurev-biochem-060614-034439.

48. Kjaergaard CH, Qayyum MF, Wong SD, Xu F, Hemsworth GR, Walton DJ, Young NA, Davies GJ, Walton PH, Johansen KS, Hodgson KO, Hedman B, Solomon EI. 2014. Spectroscopic and computational insight into the activation of $\mathrm{O} 2$ by the mononuclear $\mathrm{Cu}$ center in polysaccharide monooxygenases. Proc Natl Acad Sci USA 111:8797-8802 http://dx.doi.org/10.1073/pnas.1408115111.

49. Westereng B, Cannella D, Wittrup Agger J, Jørgensen H, Larsen Andersen M, Eijsink VGH, Felby C. 2015. Enzymatic cellulose oxidation is linked to lignin by long-range electron transfer. Sci Rep 5:18561 http://dx.doi.org/10.1038/srep18561.

50. Eijsink VGH, Vaaje-Kolstad G, Vårum KM, Horn SJ. 2008. Towards new enzymes for biofuels: lessons from chitinase research. Trends Biotechnol 26:228-235 http://dx.doi.org/10.1016/j.tibtech.2008.02.004.

51. Busk PK, Lange L. 2015. Classification of fungal and bacterial lytic polysaccharide monooxygenases. BMC Genomics 16:368. http://dx.doi .org/10.1186/s12864-015-1601-6.

52. Hemsworth GR, Henrissat B, Davies GJ, Walton PH. 2014. Discovery and characterization of a new family of lytic polysaccharide monooxygenases. Nat Chem Biol 10:122-126 http://dx.doi.org/10.1038 /nchembio.1417.

53. Lo Leggio L, Simmons TJ, Poulsen J-CN, Frandsen KEH, Hemsworth GR, Stringer MA, von Freiesleben P, Tovborg M, Johansen KS, De Maria L, Harris PV, Soong C-L, Dupree P, Tryfona T, Lenfant N, Henrissat B, Davies GJ, Walton PH. 2015. Structure and boosting activity of a starchdegrading lytic polysaccharide monooxygenase. Nat Commun 6:5961 http://dx.doi.org/10.1038/ncomms6961.

54. Agger JW, Isaksen T, Várnai A, Vidal-Melgosa S, Willats WGT, Ludwig R, Horn SJ, Eijsink VGH, Westereng B. 2014. Discovery of LPMO activity on hemicelluloses shows the importance of oxidative processes in plant cell wall degradation. Proc Natl Acad Sci USA 111: 6287-6292 http://dx.doi.org/10.1073/pnas.1323629111.

55. Lange L, Huang Y, Busk PK. 2016. Microbial decomposition of keratin in nature: a new hypothesis of industrial relevance. Appl Microbiol Biotechnol 100:2083-2096 http://dx.doi.org/10.1007/s00253-015-7262-1.

56. Busk PK, Lange L. August 2012. A novel method of providing a library of n-mers or biopolymers. US patent 2012/101151.

57. Busk PK, Lange L. 2013. Cellulolytic potential of thermophilic species from four fungal orders. AMB Express 3:47 http://dx.doi.org/10.1186 12191-0855-3-47. 
58. Bayer EA, Chanzy H, Lamed R, Shoham Y. 1998. Cellulose, cellulases and cellulosomes. Curr Opin Struct Biol 8:548-557 http://dx.doi.org /10.1016/S0959-440X(98)80143-7.

59. Brunecky R, Alahuhta M, Xu Q, Donohoe BS, Crowley MF, Kataeva IA, Yang S-J, Resch MG, Adams MWW, Lunin VV, Himmel ME, Bomble YJ. 2013. Revealing nature's cellulase diversity: the digestion mechanism of Caldicellulosiruptor bescii CelA. Science 342:1513-1516.

60. Martinez D, Berka RM, Henrissat B, Saloheimo M, Arvas M, Baker SE, Chapman J, Chertkov O, Coutinho PM, Cullen D, Danchin EGJ, Grigoriev IV, Harris P, Jackson M, Kubicek CP, Han CS, Ho I, Larrondo LF, de Leon AL, Magnuson JK, Merino S, Misra M, Nelson B, Putnam N, Robbertse B, Salamov AA, Schmoll M, Terry A, Thayer N, WesterholmParvinen A, Schoch CL, Yao J, Barabote R, Nelson MA, Detter C, Bruce D, Kuske CR, Xie G, Richardson P, Rokhsar DS, Lucas SM, Rubin EM, Dunn-Coleman N, Ward M, Brettin TS. 2008. Genome sequencing and analysis of the biomass-degrading fungus Trichoderma reesei (syn. Hypocrea jecorina). Nat Biotechnol 26:553-560 http://dx.doi.org /10.1038/nbt1403.

61. Naas AE, Mackenzie AK, Mravec J, Schückel J, Willats WGT, Eijsink VGH, Pope PB. 2014. Do rumen Bacteroidetes utilize an alternative mechanism for cellulose degradation? MBio 5:e01401-14. doi:10.1128 /mBio.01401-14 http://dx.doi.org/10.1128/mBio.01401-14.

62. Ekborg NA, Morrill W, Burgoyne AM, Li L, Distel DL. 2007. CelAB, a multifunctional cellulase encoded by Teredinibacter turnerae T7902T, a culturable symbiont isolated from the wood-boring marine bivalve Lyrodus pedicellatus. Appl Environ Microbiol 73:7785-7788 http://dx .doi.org/10.1128/AEM.00876-07.

63. Rothberg JM, Leamon JH. 2008. The development and impact of 454 sequencing. Nat Biotechnol 26:1117-1124 http://dx.doi.org/10.1038 $\underline{\text { Inbt1485. }}$.

64. Huang Y, Busk PK, Lange L. 2015. Production and characterization of keratinolytic proteases produced by Onygena corvina. Fungal Genom Biol 4:119.

65. Huang Y, Busk PK, Herbst FA, Lange L. 2015. Genome and secretome analyses provide insights into keratin decomposition by novel proteases from the non-pathogenic fungus Onygena corvina. Appl Microbiol Biotechnol 99:9635-9649 http://dx.doi.org/10.1007/s00253-015-6805-9.

66. Alaswad A, Dassisti M, Prescott T, Olabi AG. 2015. Technologies and developments of third generation biofuel production. Renew Sustain Energy Rev 51:1446-1460 http://dx.doi.org/10.1016/j.rser.2015.07.058. 67. Hotchkiss AT, Olano-Martin E, Grace WE, Gibson GR, Rastall RA. 2003. Pectic oligosaccharides as prebiotics, p 5-54. In Eggleston G, Côté GL (ed), Oligosaccharides in Food and Agriculture. ACS Publications, American Chemical Society, Washington, DC.

68. Broekaert WF, Courtin CM, Verbeke K, Van de Wiele T, Verstraete W, Delcour JA. 2011. Prebiotic and other health-related effects of cerealderived arabinoxylans, arabinoxylan-oligosaccharides, and xylooligosaccharides. Crit Rev Food Sci Nutr 51:178-194 http://dx.doi.org/10.1080 110408390903044768.

69. Yao S, Mikkelsen MJ. 2010. Metabolic engineering to improve ethanol production in Thermoanaerobacter mathranii. Appl Microbiol Biotechnol 88:199-208 http://dx.doi.org/10.1007/s00253-010-2703-3.

70. Larsen L, Nielsen P, Ahring BK. 1997. Thermoanaerobacter mathranii sp. nov., an ethanol-producing, extremely thermophilic anaerobic bacterium from a hot spring in Iceland. Arch Microbiol 168:114-119 http://dx .doi.org/10.1007/s002030050476.

71. Grauslund M, Lopes JM, Rønnow B. 1999. Expression of GUT1, which encodes glycerol kinase in Saccharomyces cerevisiae, is controlled by the positive regulators $\mathrm{Adr} 1 \mathrm{p}$, Ino2p and Ino4p and the negative regulator Opi1p in a carbon source-dependent fashion. Nucleic Acids Res 27:4391-4398 http://dx.doi.org/10.1093/nar/27.22.4391.

72. Pavlik P, Simon M, Schuster T, Ruis H. 1993. The glycerol kinase (GUT1) gene of Saccharomyces cerevisiae: cloning and characterization. Curr Genet 24:21-25 http://dx.doi.org/10.1007/BF00324660.
73. Rønnow B, Kielland-Brandt MC. 1993. GUT2, a gene for mitochondrial glycerol 3-phosphate dehydrogenase of Saccharomyces cerevisiae. Yeast 9:1121-1130 http://dx.doi.org/10.1002/yea.320091013. 74. Andersen AS, Sandvang D, Schnorr KM, Kruse T, Neve S, Joergensen B, Karlsmark T, Krogfelt KA. 2010. A novel approach to the antimicrobial activity of maggot debridement therapy. J Antimicrob Chemother 65:1646-1654 http://dx.doi.org/10.1093/jac/dkq165.

75. Ragauskas AJ, Williams CK, Davison BH, Britovsek G, Cairney J, Eckert CA, Frederick WJ Jr, Hallett JP, Leak DJ, Liotta CL, Mielenz JR, Murphy R, Templer R, Tschaplinski T. 2006. The path forward for biofuels and biomaterials. Science 311:484-489 http://dx.doi.org/10.1126 /science.1114736.

76. Ragauskas AJ, Beckham GT, Biddy MJ, Chandra R, Chen F, Davis MF, Davison BH, Dixon RA, Gilna P, Keller M, Langan P, Naskar AK, Saddler JN, Tschaplinski TJ, Tuskan GA, Wyman CE. 2014. Lignin valorization: improving lignin processing in the biorefinery. Science 344:1246843 http://dx.doi.org/10.1126/science.1246843.

77. Bech L, Herbst F, Grell M, Hai Z, Lange L. 2015. On-site enzyme production by Trichoderma asperellum for the degradation of duckweed. Fungal Genom Biol 5:126 http://dx.doi.org/10.4172/2165-8056.1000126. 78. Penttilä M, Nevalainen H, Rättö M, Salminen E, Knowles J. 1987. A versatile transformation system for the cellulolytic filamentous fungus Trichoderma reesei. Gene 61:155-164 http://dx.doi.org/10.1016/0378 -1119(87)90110-7.

79. Berka RM, Schneider P, Golightly EJ, Brown SH, Madden M, Brown KM, Halkier T, Mondorf K, Xu F. 1997. Characterization of the gene encoding an extracellular laccase of Myceliophthora thermophila and analysis of the recombinant enzyme expressed in Aspergillus oryzae. Appl Environ Microbiol 63:3151-3157.

80. Skjøt M, Kauppinen S, Kofod LV, Fuglsang C, Pauly M, Dalbøge H, Andersen LN. 2001. Functional cloning of an endo-arabinanase from Aspergillus aculeatus and its heterologous expression in A. oryzae and tobacco. Mol Genet Genomics 265:913-921 http://dx.doi.org/10.1007 /s004380100489.

81. Dean RA, Timberlake WE. 1989. Production of cell wall-degrading enzymes by Aspergillus nidulans: a model system for fungal pathogenesis of plants. Plant Cell 1:265-273 http://dx.doi.org/10.1105/tpc.1.3.265.

82. Pel HJ, et al. 2007. Genome sequencing and analysis of the versatile cell factory Aspergillus niger CBS 513.88. Nat Biotechnol 25:221-231 http://dx.doi.org/10.1038/nbt1282.

83. Schuster E, Dunn-Coleman N, Frisvad JC, Van Dijck PW. 2002. On the safety of Aspergillus niger: a review. Appl Microbiol Biotechnol 59:426-435 http://dx.doi.org/10.1007/s00253-002-1032-6.

84. Berka RM, Rey MW, Brown KM, Byun T, Klotz AV. 1998. Molecular characterization and expression of a phytase gene from the thermophilic fungus Thermomyces lanuginosus. Appl Environ Microbiol 64: 4423-4427.

85. Jain KK, Bhanja Dey T, Kumar S, Kuhad RC. 2015. Production of thermostable hydrolases (cellulases and xylanase) from Thermoascus aurantiacus RCKK: a potential fungus. Bioprocess Biosyst Eng 38:787796 http://dx.doi.org/10.1007/s00449-014-1320-4.

86. van Zyl WH, Lynd LR, den Haan R, McBride JE. 2007. Consolidated bioprocessing for bioethanol production using Saccharomyces cerevisiae. Adv Biochem Eng Biotechnol 108:205-235 http://dx.doi.org/10.1007 110_2007_061.

87. Macauley-Patrick S, Fazenda ML, McNeil B, Harvey LM. 2005. Heterologous protein production using the Pichia pastoris expression system. Yeast 22:249-270 http://dx.doi.org/10.1002/yea.1208.

88. Visser H, Joosten V, Punt PJ, Gusakov AV, Olson PT, Joosten R, Bartels J, Visser J, Sinitsyn AP, Emalfarb MA, Verdoes JC, Wery J. 2011. Development of a mature fungal technology and production platform for industrial enzymes based on a Myceliophthora thermophila isolate, previously known as Chrysosporium lucknowense C1. Ind Biotechnol (New Rochelle NY) 7:214-223 http://dx.doi.org/10.1089/ind.2011.7.214. 
89. Taylor JW, Berbee ML. 2006. Dating divergences in the fungal tree of life: review and new analyses. Mycologia 98:838-849 http://dx.doi.org 110.3852/mycologia.98.6.838.

90. Joshi C. 2014. Du Pont: producing cellulosic ethanol. http://biofuel uptodate.com/du-pont/.

91. Kawai T, Nakazawa H, Ida N, Okada H, Tani S, Sumitani J, Kawaguchi T, Ogasawara W, Morikawa Y, Kobayashi Y. 2012. Analysis of the saccharification capability of high-functional cellulase JN11 for various pretreated biomasses through a comparison with commercially available counterparts. J Ind Microbiol Biotechnol 39:1741-1749 http:// dx.doi.org/10.1007/s10295-012-1195-9.

92. Gusakov AV. 2011. Alternatives to Trichoderma reesei in biofuel production. Trends Biotechnol 29:419-425 http://dx.doi.org/10.1016 /j.tibtech.2011.04.004.

93. Gurramkonda C, Adnan A, Gäbel T, Lünsdorf H, Ross A, Nemani SK, Swaminathan S, Khanna N, Rinas U. 2009. Simple high-cell density fedbatch technique for high-level recombinant protein production with Pichia pastoris: application to intracellular production of hepatitis B surface antigen. Microb Cell Fact 8:13 http://dx.doi.org/10.1186/1475-2859-8 $\underline{-13}$.

94. Rytioja J, Hildén K, Yuzon J, Hatakka A, de Vries RP, Mäkelä MR. 2014. Plant-polysaccharide-degrading enzymes from Basidiomycetes. Microbiol Mol Biol Rev 78:614-649 http://dx.doi.org/10.1128/MMBR $.00035-14$.

95. Yoder WT, Lehmbeck J. 2004. Heterologous expression and protein secretion in filamentous fungi, p 201-219. In Tkacz JS, Lange L (ed), Advances in Fungal Biotechnology for Industry, Agriculture, and Medicine. Kluwer Academic/Plenum Publishers, New York, NY. http://dx.doi .org/10.1007/978-1-4419-8859-1_9

96. Gouka RJ, Punt PJ, van den Hondel CAMJJ. 1997. Efficient production of secreted proteins by Aspergillus: progress, limitations and prospects. Appl Microbiol Biotechnol 47:1-11 http://dx.doi.org/10.1007 /s002530050880.

97. Hamann T, Lange L. 2006. Discovery, cloning and heterologous expression of secreted potato proteins reveal erroneous pre-mRNA splicing in Aspergillus oryzae. J Biotechnol 126:265-276 http://dx.doi.org/10.1016 /.j.jbiotec.2006.04.026.

98. FDA. 2016. Generally recognized as safe (GRAS). http://www.fda .gov/Food/IngredientsPackagingLabeling/GRAS/.

99. Mhuantong W, Charoensawan V, Kanokratana P, Tangphatsornruang S, Champreda V. 2015. Comparative analysis of sugarcane bagasse metagenome reveals unique and conserved biomass-degrading enzymes among lignocellulolytic microbial communities. Biotechnol Biofuels 8:16 http://dx .doi.org/10.1186/s13068-015-0200-8.

100. Dalbøge H, Lange L. 1998. Using molecular techniques to identify new microbial biocatalysts. Trends Biotechnol 16:265-272 http://dx.doi .org/10.1016/S0167-7799(98)01202-5.

101. Araújo R, Casal M, Cavaco-Paulo A. 2008. Application of enzymes for textile fibres processing. Biocatalysis Biotransform 26:332-349 http:// dx.doi.org/10.1080/10242420802390457.

102. Kirk O, Borchert TV, Fuglsang CC. 2002. Industrial enzyme applications. Curr Opin Biotechnol 13:345-351 http://dx.doi.org/10.1016 IS0958-1669(02)00328-2.

103. Landbo AK, Kaack K, Meyer AS. 2007. Statistically designed two step response surface optimization of enzymatic prepress treatment to increase juice yield and lower turbidity of elderberry juice. Innov Food Sci Emerg Technol 8:135-142 http://dx.doi.org/10.1016/j.ifset.2006.08.006.

104. Sarkar J, Khalil E, Solaiman M. 2014. Effect of enzyme washing combined with pumice stone on the physical, mechanical and color properties of denim garments. Int J Res Advent Technol 2:65-68.
105. Forth P, Merz T. June 2010. Laundry compositions and methods of use. European patent WO2010064086A1.

106. Schülein M. 1997. Enzymatic properties of cellulases from Humicola insolens. J Biotechnol 57:71-81 http://dx.doi.org/10.1016/S0168-1656 (97)00090-4.

107. Punt PJ, van Biezen N, Conesa A, Albers A, Mangnus J, van den Hondel C. 2002. Filamentous fungi as cell factories for heterologous protein production. Trends Biotechnol 20:200-206 http://dx.doi.org /10.1016/S0167-7799(02)01933-9.

108. Gasser CS, Fraley RT. 1989. Genetically engineering plants for crop improvement. Science 244:1293-1299 http://dx.doi.org/10.1126/science .244 .4910 .1293 .

109. Tiedje JM, Colwell RK, Grossman YL, Hodson RE, Lenski RE, Mack RN, Regal PJ. 1989. The planned introduction of genetically engineered organisms: ecological considerations and recommendations. Ecology 70:298-315 http://dx.doi.org/10.2307/1937535.

110. Khosla C, Bailey JE. 1988. Heterologous expression of a bacterial haemoglobin improves the growth properties of recombinant Escherichia coli. Nature 331:633-635 http://dx.doi.org/10.1038/331633a0.

111. Ito S, Kobayashi T, Hatada Y, Horikoshi K. 2005. Enzymes in modern detergents, p 151-161. In Barredo JL (ed), Microbial Enzymes and Biotransformations. Humana Press, Totowa, NJ. http://dx.doi.org $\underline{\text { 110.1385/1-59259-846-3:151 }}$

112. Ministry of Environment and Food of Denmark. Regulering af transport af GMO. http://mst.dk/virksomhed-myndighed/genteknologi /transport-af-gmo/regulering/.

113. Chang Y, Wang S, Sekimoto S, Aerts AL, Choi C, Clum A, LaButti KM, Lindquist EA, Yee Ngan C, Ohm RA, Salamov AA, Grigoriev IV, Spatafora JW, Berbee ML. 2015. Phylogenomic analyses indicate that early fungi evolved digesting cell walls of algal ancestors of land plants. Genome Biol Evol 7:1590-1601 http://dx.doi.org/10.1093/gbe/evv090.

114. Wahleithner JA, Xu F, Brown KM, Brown SH, Golightly EJ, Halkier T, Kauppinen S, Pederson A, Schneider P. 1996. The identification and characterization of four laccases from the plant pathogenic fungus Rhizoctonia solani. Curr Genet 29:395-403 http://dx.doi.org/10.1007 /BF02208621.

115. Jacobsen J, Lydolph M, Lange L. 2005. Culture independent PCR: an alternative enzyme discovery strategy. J Microbiol Methods 60:63-71 http://dx.doi.org/10.1016/j.mimet.2004.08.013.

116. Schulein M, Henriksen T, Andersen LN, Lassen SF, Kauppinen MS, Lange L, Nielsen RI, Takagi S, Ihara M. May 2010. Endoglucanases. US Patent 20100107342.

117. Eijsink VGH, Gåseidnes S, Borchert TV, van den Burg B. 2005. Directed evolution of enzyme stability. Biomol Eng 22:21-30 http://dx .doi.org/10.1016/j.bioeng.2004.12.003.

118. Ness JE, Kim S, Gottman A, Pak R, Krebber A, Borchert TV, Govindarajan S, Mundorff EC, Minshull J. 2002. Synthetic shuffling expands functional protein diversity by allowing amino acids to recombine independently. Nat Biotechnol 20:1251-1255 http://dx.doi.org /10.1038/nbt754.

119. Cherry JR, Fidantsef AL. 2003. Directed evolution of industrial enzymes: an update. Curr Opin Biotechnol 14:438-443 http://dx.doi.org /10.1016/S0958-1669(03)00099-5.

120. Crameri A, Raillard SA, Bermudez E, Stemmer WP. 1998. DNA shuffling of a family of genes from diverse species accelerates directed evolution. Nature 391:288-291 http://dx.doi.org/10.1038/34663.

121. Stemmer WP. 1994. Rapid evolution of a protein in vitro by DNA shuffling. Nature 370:389-391 http://dx.doi.org/10.1038/370389a0.

122. Schuster SC. 2008. Next-generation sequencing transforms today's biology. Nat Methods 5:16-18 http://dx.doi.org/10.1038/nmeth1156. 